\title{
Occupational Dose Estimates for a Monitored Retrievable Storage Facility
}

\author{
R. Harty \\ G. A. Stoetzel
}

June 1986

Prepared for the U.S. Department of Energy under Contract DE-AC06-76RLO 1830

Pacific Northwest Laboratory Operated for the U.S. Department of Energy by Battelle Memorial Institute 


\title{
DISCLAIMER
}

This report was prepared as an account of work sponsored by an agency of the United States Government. Neither the United States Government nor any agency thereof, nor any of their employees, makes any warranty, express or implied, or assumes any legal liability or responsibility for the accuracy, completeness, or usefulness of any information, apparatus, product, or process disclosed, or represents that its use would not infringe privately owned rights. Reference herein to any specific commercial product, process, or service by trade name, trademark, manufacturer, or otherwise, does not necessarily constitute or imply its endorsement, recommendation, or favoring by the United States Government or any agency thereof. The views and opinions of authors expressed herein do not necessarily state or reflect those of the United States Government or any agency thereof.

\author{
PACIFIC NORTHWEST LABORATORY \\ operated by \\ BATTELLE \\ for the \\ UNITED STATES DEPARTMENT OF ENERGY \\ under Contract DE-AC06-76RLO 1830
}

\begin{tabular}{|c|c|}
\hline \multirow{2}{*}{\multicolumn{2}{|c|}{ Printed in the United States of America }} \\
\hline \multirow{2}{*}{\multicolumn{2}{|c|}{$\begin{array}{l}\text { Available from } \\
\text { National Technical Information Service }\end{array}$}} \\
\hline & \\
\hline \multicolumn{2}{|c|}{ United States Department of Commerce } \\
\hline \multicolumn{2}{|c|}{ S285 Port Royal Road } \\
\hline \multicolumn{2}{|c|}{ Springfield, Virginia 22161} \\
\hline \multirow{2}{*}{\multicolumn{2}{|c|}{$\begin{array}{l}\text { NTIS Price Codes } \\
\text { Microfiche A01 }\end{array}$}} \\
\hline & \\
\hline \multicolumn{2}{|c|}{ Printed Copy } \\
\hline & \\
\hline Pages & Codes \\
\hline $001-025$ & A02 \\
\hline $026-050$ & $\mathrm{~A} 03$ \\
\hline $051-075$ & A04 \\
\hline $076-100$ & A05 \\
\hline $101-125$ & A06 \\
\hline $126-150$ & A07 \\
\hline $151-175$ & $A 08$ \\
\hline $176-200$ & $A 09$ \\
\hline $201-225$ & A010 \\
\hline $226-250$ & A011 \\
\hline $251-275$ & A012 \\
\hline $276-300$ & A013 \\
\hline
\end{tabular}


PNL -5744

UC -85

OCCUPATIONAL DOSE ESTIMATES FOR A

MONITORED RETRIEVABLE STORAGE FACILITY

R. Harty
G. A. Stoetze1

June 1986

Prepared for

the U.S. Department of Energy

under Contract DE-AC06-76RLO 1830

Pacific Northwest Laboratory

Richland, Washington 99352 
,

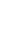


ABSTRACT

Occupational doses were estimated for radiation workers at the monitored retrievable storage (MRS) facility. This study provides an estimate of the occupational dose based on the current MRS facility design, examines the extent that various design parameters and assumptions affect the dose estimates, and identifies the areas and activities where exposures can be reduced most effectively.

The occupational doses were estimated for both the primary storage concept and the alternate storage concept. The dose estimates indicate the annual dose to all radiation workers will be below the $5 \mathrm{rem} / \mathrm{yr}$ federal dose equivalent limit. However, the estimated dose to most of the receiving and storage crew (the workers responsible for the receipt, storage, and surveillance of the spent fuel and its subsequent retrieval), to the crane maintenance technicians, and to the cold and remote maintenance technicians is above the design objective of $1 \mathrm{rem} / \mathrm{yr}$. The highest annual dose is received by the riggers $(4.7 \mathrm{rem})$ in the receiving and storage crew.

An indication of the extent to which various design parameters and assumptions affect the dose estimates was obtained by changing various design-based assumptions such as work procedures (assuming specific operations are remote), background dose rates in radiation zones, and the amount of fuel received and stored annually. The study indicated that a combination of remote operations, increased shielding, and additional personnel (for specific jobs) or changes in operating procedures will be necessary to reduce worker doses below $1.0 \mathrm{rem} / \mathrm{yr}$. Operations that could be made at Teast partially remote include the removal and replacement of the tiedowns, impact limiters, and personnel barriers from the shipping casks and the removal or installation of the inner closure boits. Reductions of the background dose rates in the receiving/ shipping and the transfer/discharge areas may be accomplished with additiona? shielding. The use of additional personnel or alternate operating procedures will decrease the annual dose to specific personnel, for example, the storage area crew chiefs. 


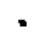 ,}




\section{FOREWORD}

This study provides an estimate of the occupational dose to radiation workers at the monitored retrievable storage (MRS) facility based on the conceptual design of an integral MRS facility. The purpose of the study is to provide an upper bound on the occupational dose estimates, to examine the need for exposure reduction, and to identify areas or tasks where exposure can be reduced most effectively.

The analysis presented in this study is consistent with the Conceptua? Design Report (CDR) prepared by the Ralph M. Parsons Company in September 1985. Since this time, the MRS mission has changed as a result of better system definitions and exchanges with state and local authorities. Thus, the Conceptual Design Report and this study do not include all of the changes that were eventually incorporated into the MRS proposal sent to Congress.

The Conceptual Design Report and the analysis contained in this report are based on a $3600 \mathrm{MTU} / \mathrm{yr}$ throughput instead of the currently expected 2500 to $3600 \mathrm{MTU} / \mathrm{yr}$. Other changes that have been made or are being considered for the integral MRS facility include the direct routing (no field storage) of canistered fuel from the MRS receiving and handling facility to the repository after full operation of the repository is attained, the planned use of nextgeneration shipping casks with greater capacity and greater potential for remote handling (although a potentially higher surface dose rate), the proposed use of large, specialized casks for transportation from the MRS to the repository, the placement of the spent-fuel canisters directly into the shipping cask or into repository-specific canisters instead of overpacking the canisters, and the absence of plans to store West Valley high-level waste at the MRS.

Because the MRS design is an ongoing project, further changes are expected. The occupational doses given in this report are not expected to be the final doses at the facility. Instead, they are a conservative estimate of the doses expected at a MRS facility based on the Conceptual Design Report, and should be used only as an indication of the areas or tasks where exposure reduction will be most effective. 
. 


\section{EXECUTIVE SUMMARY}

Occupational doses were estimated for radiation workers at the monitored retrievable storage (MRS) facility. This report provides an estimate of the occupational dose based on the conceptual design of an integral MRS facility, examines the need for exposure reduction, indicates the extent that various design parameters and assumptions affect the dose estimates, and identifies the most probable areas or activities amenabie to exposure reduction to be pursued in the final design phase.

The occupational doses were estimated for both the primary storage concept (sealed storage casks) and the alternate storage concept (field drywells). Parameters used as the basis for the calculations were taken or derived from information in the Conceptual Design Report for the integral MRS facility. If the information necessary for this study was not in the design reports, assumptions were made as documented in this report. When assumptions were required to complete the dose estimates, the assumptions tended to be conservative and thus the dose estimates are conservatively high.

The purpose of this report is to evaluate the dose estimates based on the job description or craft of the radiation zone workers at the MRS facitity. This allows the most effective means of identifying the jobs and tasks where exposure reduction is necessary.

The radiation workers at the MRS facility were divided into two groups and the dose estimates were calculated separately for each group. The first group is the receiving and storage crew, which includes the millwrights, riggers, technicians, crane operators, supervisors and storage area inspectors. These workers are responsible for the receipt, storage and surveillance of the spent fuel and its subsequent retrieval and shipment to a final repository. The second group of radiation workers at the MRS facility is referred to as the "other radiation worker" crew. This group includes the shielded process cell operators, receiving and handling buitding maintenance and services personnel, analytical laboratory personnel, health physics personnel, manipulator maintenance personnel, and HVAC (heating, ventilation, and air conditioning) maintenance personnel. 
The following conclusions resulted from the dose estimates for the receiving and storage crew.

- The estimated annual dose to all members of the receiving and storage crew is below the $5 \mathrm{rem} / \mathrm{yr}$ federal dose equivalent limit. However, the doses to the technicians, crane operators, riggers, millwrights, and storage area crew chief are above the design dose objective of $1 \mathrm{rem} / \mathrm{yr}$. The highest annual dose is received by the riggers $(4.7 \mathrm{rem})$.

- The recejpt, inspection and untoading of the shipping cask and the shipment of the waste to the permanent repository account for $91 \%$ of the dose to the receiving and storage crew for the primary storage concept and $64 \%$ of the dose to the receiving and storage crew for the alternate storage concept. The task with the highest exposure is the removal and replacement of the tiedowns, impact limiters, and personnel barriers from the shipping cask.

- The total dose estimated for the receiving and storage crew for the alternate storage concept is about $60 \%$ greater than the dose estimated for the primary storage concept. This is because workers would receive a higher dose during spent fuel and high-Tevel waste emplacement in and retrieval from the drywell storage area.

The dose estimates resulted in the following conclusions for the personne] in the other radiation worker crew.

- The annual dose received by the crane maintenance technicians and the cold and remote maintenance technicians may be above the design objective of $1 \mathrm{rem} / \mathrm{yr}$. The dose to the remaining personnel will likely be below the design objective.

- The dose estimates for the other radiation worker crew are the same for the primary and alternate storage concepts.

An indication of the possible variation in the dose estimates can be obtained by changing various design-based assumptions such as the work procedures (for instance, assuming some operations are remote), the background dose rates in the radiation zones, or the amount of spent fuel received and stored 
annually. By making tasks with the high exposure rates remote (the removal and replacement of the tiedowns, impact limiters, and personnel barriers from the shipping cask and the removal or installation of the inner closure bolts), the average annual dose to the riggers is reduced by $63 \%$. Lesser reductions were noted for other crafts involved with the task. Reducing background dose rates in the receiving/shipping and the transfer/discharge areas (e.g., $0.75 \mathrm{mrem} / \mathrm{hr}$ to $0.4 \mathrm{mren} / \mathrm{hr}$ ) results in annual dose reductions ranging from 0 to $16 \%$ for the personnel with doses above the design criteria. Assuming a 3,000 MTU/yr throughput capacity for the MRS facility instead of 3,600 MTU/yr (without varying the number of personnel) reduces annual worker doses by up to $17 \%$.

A combination of remote operations, increased shielding, and either the use of additional personnel for specific jobs or changes in operating procedures appears to be necessary to reduce worker doses below $1.0 \mathrm{rem} / \mathrm{yr}$. Operations that could conceivably be made at least partially remote include the removal or installation of the tiedowns, impact limiters, and personnel barriers from the shipping casks, preparations for removing the shipping cask, positioning of the cask lifting yoke, and the loosening of the bolts on the inner cask closure lid.

Shielding can be placed in appropriate locations in the receiving/shipping and transfer/discharge areas to reduce the background dose rates to personnel in these areas. Shielding can also be placed on pickup trucks, cranes, and transport vehicles to reduce the annual dose to the storage area crews.

The use of additional personnel or alternate operating procedures would decrease the dose to the storage area crew chiefs by decreasing the amount of time a given individual is in the storage area.

The information used to obtain the dose estimates will need to be confirmed as the facility design is refined and as methods for reducing dose to the workers are incorporated. These future analyses will provide a clearer indication of the personnel doses expected for the facility. 


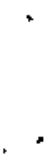




\section{ACXNOWLEDGMENTS}

The authors wish to express their appreciation to Dave S. Jackson, Roy M. Gale, Robert E. Heineman, Joan M. Mulvehill, John G. Meyers, W. Dan Reece, and Larry W. Brackenbush for their technical input and assistance. He would also like to thank Ann Marshall for technical editing and Steve $D$. Miller for assistance in performing the computer shielding calculations. Our appreciation is extended to Marianna Cross for typing the initial draft and to Toni Jewell for typing the final report. 


\section{•}

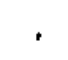




\section{CONTENTS}

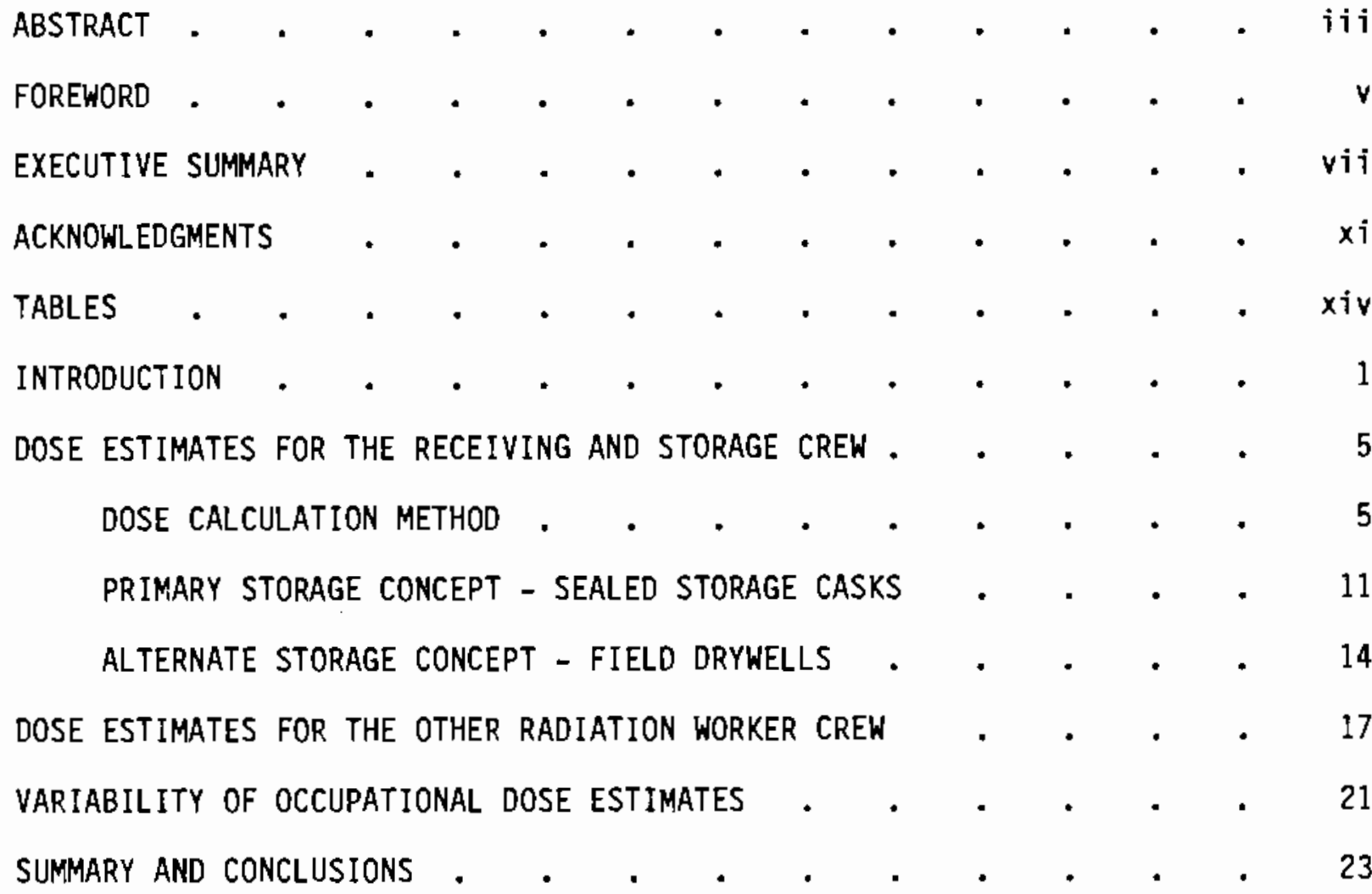

APPENDIX A - BASIS FOR DOSE ESTIMATES TO WORKERS DURING THE STORAGE, SURVEILLANCE AND RETRIEVAL OF WASTE IN SEALED

STORAGE CASKS

APPENDIX B - BASIS FOR DOSE ESTIMATES TO WORKERS DURING THE STORAGE, SURVEILLANCE AND RETRIEVAL OF WASTE IN DRYWELL

STORAGE

8.1

REFERENCES 
TABLES

1 Receiving and Storage Crew . . . . . . . . . 25

2 Exposure Rates at Various Distances from a Spent-Fuel

Shipping Cask Received at the MRS Facility . • . . . 26

3 Storage Area Capacities . . . . . . . . . . . . . . 27

4 Receipt, Inspection, and Unloading of Shipping Casks . . . 28

5 Transfer of Waste Canisters from Process Cells into

Storage Casks . . . . . . . . . . . 30

6 Emplacement of Storage Casks in the Storage Area . . . . 31

7 Surveillance and Inspection of Storage Casks in the

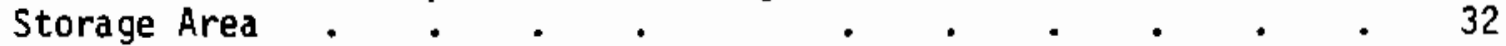

8 Retrieval of Storage Casks from the Storage Area . . . . . 33

9 Transfer of Waste Canisters from Storage Casks into

Process Cells . $. \quad . \quad . \quad . \quad . \quad . \quad . \quad . \quad . \quad 34$

10 Loading and Shipment of Repository Overpacks (RO) and

Shipping Casks for Repository Overpacks (SCFRO) . . . . 35

11 Summary of Task Dose from Spent-Fuel Receipt, Storage, and

Shipment Operations - Primary Storage Concept. . . . . 37

12 Annual Dose to the Receiving and Storage Crew - Primary

Storage Concept . . . . . . . . . 38

13 Transfer of Waste Canisters from Process Cells into Transfer

14 Surveillance and Inspection of Drywells . . . . . . . 41

15 Retrieval of Waste Canisters from Drywell Storage Area and

Transfer into Process Cells . . . . . . . . . . 42

16 Summary of Task Dose from Spent-Fuel Receipt, Storage, and 44

17 Annual Dose to the Receiving and Storage Crew - ATternate
Storage Concept . . . . . . . . 45 
18 Dose Estimates for the Other Radiation Worker Crew . . . 46

19 Results of Variation of Design Basis Assumptions - Primary

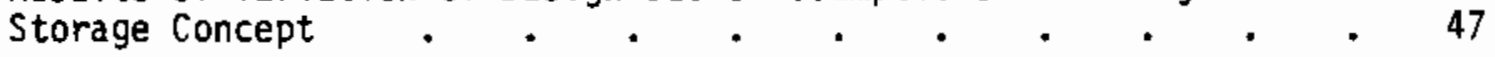

20 Results of Variation of Design Basis Assumptions - Alternate

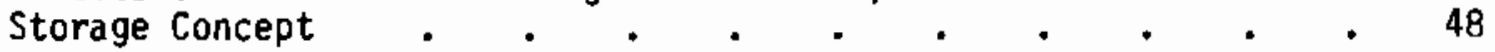


,

, 
OCCUPATIONAL DOSE ESTIMATES FOR A

MONITORED RETRIEVABLE STORAGE FACILITY

\section{INTRODUCTION}

Occupational doses were estimated for personnel working at the monitored retrievable storage (MRS) facility. The doses were estimated for both the primary storage concept (sealed storage casks) and the alternate storage concept (field drywells). The dose estimates are based on the information contained in the Conceptual Design Report (The Ralph M. Parsons Company 1985a) and the Conceptual Basis for Design (The Ralph M. Parsons Company 1985b) for the integral monitored retrievable storage facility.

The radiological design criteria for the MRS facility as given in the Conceptual Basis for Design (The Raiph M. Parsons Company 1985b) include the requirements of the Department of Energy (DOE) specified in the DOE Order 5480.1 (1981). The DOE Order states that "Onsite personnel exposure levels less than one-fifth of the permissible dose equivalent limits prescribed in this chapter should be used as a design objective." The current permissible dose equivalent limit to the whole body is 5 rem annually, with 3 rem allowed during any calendar quarter. Thus, $1 \mathrm{rem} / \mathrm{yr}$ is the design objective for the MRS facility.

This study was performed to provide an estimate of the occupational dose based on the current facility design, to examine the need for exposure reduction, to indicate the extent that various design parameters and assumptions affect the dose estimates, and to identify the areas or tasks where exposures can be reduced most effectively. This study may also be used as a base case for future optimization studies and ALARA analyses.

In keeping with the purpose of this report, a total dose for the facility was not calculated. Instead, the dose estimates were evaluated based on the job description or craft of the radiation zone workers at the MRS facility. This allowed the most effective means of identifying the jobs and tasks where exposure reduction was necessary. 
Two approaches were used to calculate the occupational dose estimates for radiation zone workers at the MRS facility. The first approach was for the receiving and storage crew, which is responsible for the receipt, storage and surveillance of the spent fuel as well as its subsequent retrieval and shipment. This crew is composed of technicians, riggers, millwrights, crane operators, supervisors and storage area inspectors. The receiving, storage, surveillance, retrieval and shipping processes are divided into well-defined tasks, and the dose was calculated for each craft during each of the tasks using the time estimates provided by the Ralph M. Parsons Company (1985a, Vol. VI, Book I) and the estimated dose rate at the lociation of each worker.

The second approach for estimating dose was for the remaining radiation workers at the MRS facility. These personnel, referred to as the "other radiation worker" crew, include the shielded process cell operators, the receiving and handling ( $R \& H)$ building maintenance and services personnel, the analytical laboratory personnel, the health physics personnel, the manipulator maintenance personne1, and the HVAC (heating, ventitation, and air conditioning) maintenance personnel. The dose to these personnel is based on the maximum expected dose rates in the rooms or areas where they work and the amount of time spent in each room or area. These dose rates were obtained from the Conceptual Design Report (The Ralph M. Parsons Company 1985a, Vol. I, Book II).

Where assumptions were required to complete the dose estimates, the assumptions tended to be conservative and thus the dose estimates are conservatively high. Although the conceptual design report and the assumptions result in conservatively high dose estimates, the estimates are based on a single purpose, large volume operation and thus the time and dose estimates may be lower than would be expected from a comparison with similar operations performed at other facilities on an infrequent basis. The dose estimates do not reflect exposure resulting from accidents or daily mishaps due to the difficulty of predicting these occurrences.

The information used to obtain the dose estimates will need to be confirmed to provide a more accurate estimate of the occupational dose. The time estimates and procedures for the various tasks should be confirmed after the actual designs and equipment have been selected. Likewise the exposure rates 
for the rooms, areas and work stations as given in the Conceptual Design Report are maximum values and may be lower after design optimization. This report provides an indication of the variation in the occupational dose that would result from changes made in the equipment design, the expected throughput, or the expected design dose rates in the facility work areas. 
. 


\section{DOSE ESTIMATES FOR THE RECEIVING AND STORAGE CREW}

Occupational doses for the members of the receiving and storage crew were estimated for both the primary storage concept (sealed storage casks) and the alternate storage concept (field drywells). The methods that were used to calculate the dose estimates and the basic information required to perform the calculations are described and the results are presented separately for each storage concept.

DOSE CALCULATION METHOD

The receiving and storage crew is responsible for the receipt, storage, surveillance (monitoring and accountability), retrieval and shipment processes occurring in the R\&H building and the storage area of the MRS facility. The dose received by the receiving and storage crew was estimated by dividing each of the five spent fuel handling processes into tasks, determining the amount of time required to perform each task, and estimating the dose rate that the workers are exposed to during each task. The dose to a worker performing a specific task is the product of the dose rate at the location of the worker and the amount of time the worker is in the specified radiation field. The majority of tasks require several workers who may be located at various distances from the source and thus in radiation fields with different intensities.

Al1 radiation zone personnel are assumed to spend an average of 5 hours each day in radiation zones ( 1250 out of $2000 \mathrm{hr} / \mathrm{yr}$ ). When workers are in a radiation zone but are not near a major source of radiation, such as a loaded shipping cask, they receive a dose based on the background dose rate in the room or work area where they are located. Generally, the workers are subject to this background dose rate when they are working on process tasks that do not involve loaded spent fuel casks and when they are in the work area but not working directly on a process task. A second background dose rate is applied to the remaining 3 hours/day during which the workers are taking breaks, processing through the change rooms, receiving training or physicals, or fulfilling administrative requirements. 
The total dose to each worker consists of the dose received by the worker while performing specifjc tasks, the background dose received while in the radiation zone but not working on a process task, and the background dose received while in the facility but not in a radiation zone.

The calculation of the dose estimates to the receiving and storage crew requires the following information:

1. a description of each task performed during the material handling processes, including the receipt, storage, surveillance, retrieval and shipment processes,

2. an estimate of the time required to complete each task,

3. the number of workers of each craft (such as millwright, rigger) required for each task,

4. the location of each worker in reference to the source,

5. the dose rate at the location of each worker,

6. the background dose rates, and

7. the amount of waste processed each year through the facility.

A description of the tasks performed during the material handling processes (item 1 in above list) is found in the Design Description section of the Conceptual Design Report (The Ralph M. Parsons Company 1985a Vo1. I, Book II). A list of the tasks performed for each of the five processes is given in Design Study 2, "Waste Receipt and Handling Characteristics of the MRS Facility" (The Ralph M. Parsons Company 1985a Vo1. VI, 80ok I).

The design study (The Ralph M. Parsons Company 1985a Vol. VI, 8ook I) contains the minimum time required to perform the stated tasks (item 2). The design study was written to demonstrate that the conceptual design meets the base case throughput requirements. It does not include much detail for those tasks that are not on the critical path, especially those tasks occurring during the storage, surveillance and retrieval processes. Assumptions were made in cases where the estimation of occupational dose required more detailed information. These assumptions are stated throughout this report and in the 
appendices. Appendix A contains the assumptions used for the primary storage concept. Appendix $B$ contains the assumptions used for the alternate storage concept.

The number of workers required for each task (item 3) and the craft of the worker are based on the description of the material handling processes in the Design Description of the Conceptual Design Report (The Ralph M. Parsons Company 1985a Vol. I, Book II). Table I (a) lists the number of workers in the receiving and storage crew. It was assumed for this analysis that the receiving and storage crew personnel listed in the table would be responsible for performing all of the tasks associated with the material handing processes. For example, a receiving and storage crew technician will be expected to perform contamination surveys of the shipping and storage casks, although a health physics technician will likely be present.

The tasks performed by the receiving and storage crew occur in three separate locations of the facility: the receiving/shipping area of the R\&H building, the transfer/discharge area of the R\&H building, and the storage area. The individual members in each craft (millwrights, riggers, technicians, and crane operators; the transport and cask cart operators are assumed to be in the same craft as the crane operators) rotate between the receiving/ shipping, the transfer/discharge and the storage areas, thus evenly dividing the total dose within a given craft. The millwrights located in the site services building are also expected to rotate through the R\&H building, and thus the dose received by the millwrights will be divided by 22 workers instead of 14. The crew supervisors, the storage area crew chief, and the storage area inspectors remain in the specific area to which they are assigned and do not rotate.

The location of each worker in reference to the surrounding radiation sources (item 4) is based on experience at other facilities with similar processes. The distance between each worker and the source is considered for each specific task.

(a) All the tables are located at the end of the main text. 
The dose rate at the location of each worker (item 5) depends on the source of the radiation, the amount of shielding between the source and the worker, and the distance the worker is from that source. The major source of radiation is the spent fuel or high-level waste. The dose rate from the spent fuel depends on whether it is in a shipping cask, a sealed storage cask, the transfer shield, or a drywell.

Dose rate information is not available for the specific shipping casks that will be used at the MRS facility. The reference truck cask contains two pressurized water reactor (PWR) fuel assemblies or five boiling water reactor (BW'R) fuel assemblies (The Ralph M. Parsons Company 1985b). The reference rail cask contains 12 PWR or 32 BWR fuel assemblies. The reference cask types, the NLI-1/2 and TN-12, either have not been used in North America or are not designed for the number of fuel assemblies or the age of fuel to be shipped to the MRS facility. Experience with other large-sized shipping casks indicates that a surface dose rate of $40 \mathrm{mrem} / \mathrm{hr}$ along the side of the cask and a dose rate of $4 \mathrm{mrem} / \mathrm{hr}$ at 6 feet from the cask is an appropriate estimate for the expected dose rate. Although the rail cask is expected to be significantly larger than the truck cask, the expected dose rates are assumed to be the same with additional shielding on the rail cask balancing out the increased source term.

The dose rate at a point outside the truck or rail cask results from the radiation field emanating from the fuel, and may be augmented by streaming through voids or penetrations in the shielding of the cask. At a distance of 6 feet, the exposure rate resulting from the general field is assumed to be $3 \mathrm{mR} / \mathrm{hr}$, and the exposure rate from the voids or penetrations in the shielding is assumed to be $1 \mathrm{mR} / \mathrm{hr}$. The exposure rate from the general radiation field at various distances from the cask was determined using the computer shielding code, ISOSHLO (Engel, Greenborg, and Hendrickson 1966; Simmons et al. 1967). A model of the $\mathrm{NLI}-1 / 2$ cask (the reference truck cask) was used for the shielding calculations (NRC 1983). The gamana source spectrum was obtained from the Conceptual Basis for Design (The RaTph M. Parsons Company 1985b). The ganda spectrum corresponded to a PWR spent fuel assembly 10 years out of the reactor with a burnup of 33,000 MWD/MTU. Two PWR fuel assemblies were assumed to be in the cask. The results were scaled to correspond to a $3 \mathrm{mR} / \mathrm{hr}$ 
exposure rate at 6 feet. The exposure rate resulting from voids or penetrations in the shielding will likely resemble a point source and thus will fall off as the inverse of the square of the distance from the cask. Table 2 illustrates the two components of the exposure rate and their intensity as the distance from the cask increases.

The dose rates from the concrete storage casks were based on information provided in Design Study 30, Concrete Cask Radiation Analysis (The Ralph M. Parsons Company 1985a, VoT. VI, Book I). The dose rate from a storage cask depends on the contents of that cask. The dose rate to the side of the cask and to the top of the cask was determined for a "typical cask" by taking a weighted average of the dose rates based on the projected number of casks placed in the storage yard during a given year. A surface dose rate of $6.8 \mathrm{mrem} / \mathrm{hr}$ was calculated for the side of a typical cask. A typical surface dose rate of $3.4 \mathrm{mrem} / \mathrm{hr}$ was calculated for the top of the cask over the gap above the cask cover, and $9.4 \mathrm{mrem} / \mathrm{hr}$ was the typical surface dose rate for the top of the cask over the gap before the cask cover was emplaced. Dose rates at various distances from the side of the cask were based on the surface dose of $6.8 \mathrm{mrem} / \mathrm{hr}$ and were calculated using the computer code CYLIN (a) and the gamma source spectrum for 33,000 MWD/MTU, 5-year cooled PWR fuel (The Ralph M. Parsons Company 1985b).

The dose rates from the loaded transfer shield and a loaded drywell in the drywell storage area were obtained from the "Radiation Analys is for Drywells and Transfer Shields" presented in Conceptual Design Report Calculations (The Ralph M. Parsons Company 1985a, Vol. IV, Book XIII).

The background dose rates in the work areas (item 6) are based on the maximum steady-state dose rate for the specific work area. The maximum steady-state design dose rates are listed in the Conceptual Design Report Design Description (The Ralph M. Parsons Company 1985a, Vol. I, Book II). The workers are subject to this dose rate when they are working on process tasks that do not involve loaded spent fuel casks, or when they are in the work area but are not working directly on a process task. A maximum background

(a) A Pacific Northwest Laboratory (PNL), unpublished, verified, in-house, point-kernal shielding code. 
dose rate of $0.75 \mathrm{mrem} / \mathrm{hr}$ was assigned during those times to personnel working in the receiving/shipping areas and the transfer/discharge areas. The storage area crew chiefs and inspectors are expected to receive a maximum dose rate of $0.125 \mathrm{mrem} / \mathrm{hr}$ during the time they are not in the storage yard.

The background dose rate during the three hours a day when the workers are not in radiation zones is also based on the maximum steady-state design dose rates. One hour is spent in low-background dose rate areas, such as the access corridor or the contaminated side of the change room, where the maximum steady-state design dose rate of $0.125 \mathrm{mrem} / \mathrm{hr}$ was used. However, the remaining two hours are spent in areas such as the administrative area, the lunch room and the clean side of the change rooms, where the dose rate is expected to be significantiy less than $0.125 \mathrm{mrem} / \mathrm{hr}$. A dose rate of zero is assigned for these two hours because the expected dose rate will be so small. The basis for the zero dose rate is the distance between the operating galleries (which have a maximum steady-state design dose rate of $0.125 \mathrm{mrem} / \mathrm{hr}$ ) and the administrative area/Tunch room facilities and the assumption that adequate shielding is present above the facility to eliminate dose from skyshine.

The MRS facility is designed for an annual triroughput (item 7) of 3600 MTU (The Ralph M. Parsons Company 1985b). An equivaient amount of waste is expected to be retrieved annually from the storage yard and shipped to the repository. It is expected that these processes will occur concurrentiy. The $3600 \mathrm{MTU} / \mathrm{yr}$ throughput requires a 7-day/week, 24-hr/dax operation. The design assumes that the spent fue] is received 70 weight percent by rail and 30 weight percent by truck and that all spent fuel and waste is shipped from the facility by rail. The dose estimates in this report are based on $3600 \mathrm{MTU} / \mathrm{yr}$ shipped into the MRS facility and $3600 \mathrm{MTU} / \mathrm{yr}$ retrieved from the storage yard and sent to the repository. This corresponds to 442 rail casks and 1,166 truck casks received each year by the facility (70\% rail/30\% truck by weight) and a total of 1319 shipping casks containing repository overpacks sent each year to the repository.

The storage area is designed for a storage capacity of 15,000 MTU of spent fuel and a small amount of high-level waste (The Ralph M. Parsons Company 1985b). The dose estimates in this report are conservatively based on the storage of the full 15,000 MTU of spent fuel concurrent to the annual 
receipt and retrieval of 3600 MTU of spent fuel. The number of seated storage casks and the number of drywells required to store the yearly quantity (3600 MTU/yr) and the number required to store the total quantity of waste are shown in Table 3, which is based on information given in the Conceptual Design Report - Design Description (The Ralph M. Parsons Company 1985a, Vol. I, Book II).

PRIMARY STORAGE CONCEPT - SEALED STORAGE CASKS

The material handling processes for the primary storage concept include receiving, inspecting, and unloading the waste, transferring the waste canisters into storage casks and placing the storage casks in the storage area, monitoring and inspecting the storage casks, retrieving the storage casks from the storage area and unloading the waste canisters into the process cells, and shipping the waste in shipping casks to the repository.

Table 4 lists the tasks that occur during the receipt, inspection, and unloading of the fuel. It includes only tasks taking place in the RoH building, not activities occurring as the spent fuel is received at the main inspection gate or into the storage yard. It also does not include activities occurring as the spent fuel is moved through the process cells. The table lists the following: craft type and number of workers required to perform each task, the estimated time required for the task, the number of workerhours required each year for receiving the fuel shipments by truck and rail, the distance between the worker and the source, the expected dose rate at the location of the workers, and the accumulated dose. This table and the following material-handiing process tables were designed to estimate worker dose and are not meant to be a guide to operations. Tasks may occur in parallel or overlap, although this is not indicated on the tables. Thus a summation of the task times is not equivalent to the cask turnaround time.

As indicated in Table 4, the task contributing the largest portion of the dose during the receiving process is the removal of the tiedowns, impact limiters, and personnel barriers from the vehicle containing the loaded cask. This task contributes $45 \%$ of the total dose for this process. Other dose intensive tasks include performing a contamination survey and completing the 
preparations for unloading the cask, loosening the bolts on the inner cask lid, obtaining a gas sample and gas pressure readings from the interior of the cask, and venting the cask.

The storage process was divided into the transfer of fuel from the process cells to the storage cask (which occurs in the R\&H building) and the transfer of the casks to the storage yard and their emplacement in the storage yard. Table 5 lists the tasks occurring during the loadout of the fuel from the process cells into the concrete storage casks. The distance between the worker and the cask, the dose rate, and the total dose are also listed. Table 6 gives the dose received by personnel during the emplacement of the concrete storage casks. The tasks occurring during the loadout of the fuel into storage casks and the emplacement of the casks in the storage area are not as dose intensive as those for the receipt and unloading of the fuel from the shipping casks. This is partly due to the increased shielding provided by the storage casks and to the smaller number of storage casks loaded and stored during a year compared to the number of shipping casks received.

Table 7 contains the parameters and the results of the dose calculation for the surveillance and inspection of the storage casks.

Table 8 illustrates the dose received during the retrieval of the concrete storage casks from the storage area. Table 9 shows the tasks required and the dose received during the process of unloading the waste canisters from the concrete storage casks into the process cells for placement into the repository overpacks.

Table 10 lists the tasks and the corresponding dose for the receipt, loading and shipment of the repository overpacks (RO) and the shipping cask for the repository overpacks (SCFRO) to the permanent repository. (a) This

(a) Although the use of repository overpacks is assumed in the conceptua 1 design, the spent-fuel canisters may be placed directly into the shipping cask or the fuel may be loaded into repository-specific canisters before it is loaded into the shipping casks. Either of these options will reduce the number of worker-hours required for the shipment of the fuel to the repository. The overall worker dose (task dose plus background) will not vary because the tasks associated with receipt of the ROs are performed at dose rates equal to the background dose rate in the receiving/shipping area. 
process is basicaliy the reverse of the receiving, inspecting, and unloading process. The most dose-intensive task is the installation of the tiedowns, impact barriers, and personnel limiters, requiring $44 \%$ of the total dose. The installation of the cover bolts, the performance of a contamination survey, and the completion of preparations for the release of the cask are also major contributors to the total dose for this process.

A summary of the dose estimates for the sealed storage cask concept facility is shown in Table 11 . The receiving, inspecting and unloading of shipping casks and the shipping of the waste to the repository account for the greatest number of worker-hours and the largest fraction (91\%) of the dose. The total dose received during the receipt of the spent fuel is similar to that received during the shipment of waste to the repository, despite the consolidation of the fuel, because nonfuel bearing components and onsite generated waste are shipped to the repository along with the consolidated fuel. The number of worker-hours required for the shipment of the waste to the repository is about $40 \%$ greater than that required for the receipt of the spent fuel, because the repository overpack and the shipping cask for the repository overpack are received separately and must both be processed.

The annual dose received by each craft in the receiving and storage crew is shown in Table 12. This includes the background dose received by the personnel when they are working in a radiation zone and the background dose received when they are not in a radiation zone. The average annual dose received is above the design objective of $1 \mathrm{rem} / \mathrm{yr}$ for a 11 personnel except the crew supervisors in the receiving/shipping and the transfer/discharge areas. All the personnel are below the federal 1 imit of $5 \mathrm{rem} / \mathrm{yr}$. The riggers receive the largest annual dose, $4.7 \mathrm{rem} /$ person.

Table 12 indicates that the zone background dose assigned to the crane operators is zero. This results from each crane operator spending greater than 1250 hours a year ( 5 hours/day) working on specific tasks or in areas where the dose rate is above the zone background dose rate. 
ALTERNATE STORAGE CONCEPT - FIELD DRYWELLS

Occupational doses were also estimated for the al ternate storage concept, the field drywells. The receiving and shipping processes for the al ternate storage concept are identical to the receiving and shipping processes for the primary storage concept. The loadout, surveillance, and retrieval processes differ.

Table 13 lists the tasks performed and the resulting dose received during the loadout of waste canisters from the process cells into the transfer shield and the subsequent emplacement of the casks in the drywell. Table 14 lists the tasks performed during the surveillance and inspection of the drywells. The retrieval of the waste from the drywells and the subsequent loadout of the waste canisters into the process cells of the R\&H building for placement in the repository overpacks are shown in Table 15.

Table 16 contains a summary of the doses received at the alternate storage concept facility during the receiving and storage processes. As explained for the primary storage concept, the receiving, inspecting and unloading process and the shipment of the waste to the repository account for the greatest number of worker-hours and the largest fraction of the dose $(64 \%)$. However, a significantly larger dose is received during the emplacement and retrieval of material from the drywell storage area than is received for the same processes at the sealed storage cask area. This is a result of the larger number of worker-hours required for the placement of waste canisters in the drywell storage area.

Table 17 contains the annual dose to each craft in the receiving and storage crew for the drywell storage concept from the receipt and storage of the waste and $i$ ts subsequent shipment. The annual dose includes the background dose received by the workers while they are working in the radiation zones and the background dose received while they are not in a radiation zone. The average annual dose is above $1 \mathrm{rem} / \mathrm{yr}$ for the technicians, crane operators, riggers, millwrights, and the storage area crew chief. All personnel are below the federal limit of $5 \mathrm{rem} / \mathrm{yr}$. The riggers receive the largest annual dose $(4.7$ rem/person). The dose received by the millwrights and the riggers is the same as for the primary storage concept because these crafts only work on the front end of the facility. 
The time estimates indicate that both the crane operators and the storage area crew chief are spending greater than 1250 hours a year ( $5 \mathrm{hr} /$ day) per person on specific tasks or in areas where the dose rate is above the zone background dose rate. Thus their zone background dose is set to zero. 
DOSE ESTIMATES FOR THE OTHER RADIATION WORKER CREW

The remaining radiation workers in the MRS facility include the shielded process cell operators, R\&H building maintenance and service personnel, analytical laboratory personnel, health physics personnel, manipulator maintenance personnel, and HVAC maintenance personnel. The dose estimates are based on the dose rates in the zones or areas where these personnel will work. The estimates are the same regardless of whether the facility is designed for concrete cask or drywell storage.

These radiation workers are also expected to spend a maximum of 5 hours a day in radiation zones, with 3 hours spent on breaks, at lunch, in change rooms, and on periodic training, physicals, and administrative requirements. Two of these three hours are spent in areas with insignificant dose rates; for this analysis the dose rate for two hours is set at zero. The third hour is assumed to be spent in an area with a maximum background dose rate of $0.125 \mathrm{mrem} / \mathrm{hr}$.

The dose rates for each area of the facility are specified in the Conceptual Design Report - Design Description (The Ralph M. Parsons Company 1985a Vol. I, Book II). These dose rates are maximum steady-state design dose rates and are thus a conservative estimate of the dose in that area. The time each worker spends in a given dose rate is based on the time the worker spends in each area of the facility. Table 18 lists the personnel, the number of hours each day that they are assumed to be located in a given radiation zone, and the annual dose received by each group of personnel.

Some personnel work the entire day in the same area or in areas with the same assigned maximum steady-state design dose rate. For instance, the shielded process cell operators work primarily in the operating galleries outside the process cells. The dose rate in all the operating galleries is $0.125 \mathrm{mrem} / \mathrm{hr}$. Likewise, the analytical laboratory workers are located in the analytical laboratory $(0.25 \mathrm{mrem} / \mathrm{hr})$ for the entire work period. The same situation occurs for the control room personnel and the materials receiving and storage personnel in the maintenance and services crew. 
Other personnel work in several areas with different dose rates. The manipulator/crane storage and maintenance personnel work part of the time in the maniputator/crane storage and maintenance rooms where the maximum dose rate is $0.25 \mathrm{mrem} / \mathrm{hr}$ and part of the time in the operating gallery where the dose rate is $0.125 \mathrm{mrem} / \mathrm{hr}$. It was assumed that these workers spend 4 of the 5 hours in the $0.25 \mathrm{mrem} / \mathrm{hr}$ zone and the remaining hour in the $0.125 \mathrm{mrem} / \mathrm{hr}$ zone. The doses received by the maintenance and services supervisor, the crew supervisors, the process cell and radwaste technicians, the crane maintenance technicians, the cold and remote maintenance technicians, and the laundry room personnel were calculated by similar methods.

The health physics (HP) personnel and the HVAC maintenance personnel move throughout the facility. The dose to the HP technicians was based on the assumption that 10 of the 52 technicians are responsible for access control, 10 are responsible for the routine program support, and 32 are involved with the maintenance and operational support. The access control HP technicians are stationed at the HP check station in a $0.125 \mathrm{mrem} / \mathrm{hr}$ radiation zone. The routine program support HP technicians are responsible for instrument source testing, the air sampling program, room smears, radioactive waste surveys, and analytical laboratory coverage. These technicians spend 4 hours/day in areas with steady-state design dose rates of $0.25 \mathrm{mrem} / \mathrm{hr}$ and I hour/day in an area with a dose rate of $0.75 \mathrm{mrem} / \mathrm{hr}$. The maintenance/operation support HP technicians provide on-demand HP coverage for routine operations or maintenance support, including manipulator repairs, filter change outs, equipment repairs, equipment decontamination, and receiving/shipping and loadout/storage activities. The major portion of their work time $(4 \mathrm{hr} /$ day) will be spent in the receiving/shipping and transfer/discharge areas of the facility in a radiation zone of $0.75 \mathrm{mrem} / \mathrm{hr}$. One hour/day is spent in maintenance areas where the maximum steady-state design dose rate is $2.5 \mathrm{mrem} / \mathrm{hr}$. The $52 \mathrm{HP}$ technicians will rotate through the various jobs, thus evenly distributing the dose. The amount of time each group of HP technicians spends in a given radiation zone was purposely adjusted to achieve an average dose of $1.0 \mathrm{rem} / \mathrm{yr}$ for all $\mathrm{HP}$ technicians. The dose to the HVAC maintenance personnel was also adjusted to result in an average worker dose of $1.0 \mathrm{mrem} / \mathrm{yr}$, because there is no information on the length of time these personnel will occupy any given area. 
Table 18 indicates that the average annual dose estimates for the crane maintenance technicians and the cold and remote maintenance technicians exceed the design objective of $20 \%$ of the federal radiation protection limits. Although the assumptions used to estimate the doses are conservative, a more in-depth study of the function of these personnel is suggested. 


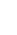

, 


\section{VARIABILITY OF OCCUPATIONAL DOSE ESTIMATES}

The MRS facility is currently in the conceptual design phase. The information on which the occupational dose estimates are based, as well as the dose estimates, will be refined as the facility design progresses. An indication of the possible variation in the occupational dose values can be obtained by changing various design-based assumptions such as the type of equipment used by the receiving and storage crew, the background dose rate in the radiation zones, and the amount of spent fuel that will actually be received by the facility. Tables 19 and 20 show the effect of any one of these changes on the average annual dose to the members of the receiving and storage crew for the primary storage concept and the alternate storage concept, respectively.

As mentioned earlier, the most dose-intensive process appears to be the receipt, inspection, and unloading of the shipping casks as well as the subsequent reshipment of the fuel to the repository. The task that results in the highest exposure is the removal and replacement of the tiedowns, impact limiters, and personnel barriers from the shipping cask. The removal (or installation) of the inner closure bolts also accounts for a significant portion of the dose. By making these operations remote (for instance, using robotics), the personnel could be moved to a distance of $20 \mathrm{ft}$ from the cask, thus lowering the expected dose rate from $15 \mathrm{mrem} / \mathrm{hr}$ (for the technicians, riggers, and millwrights) or $2.5 \mathrm{mrem} / \mathrm{hr}$ (for the crane operators) to $1.0 \mathrm{mrem} / \mathrm{hr}$. This witl Tower the average annual dose to the technicians, crane operators, riggers and millwrights as indicated in Tables 19 and 20 . The average annual dose to the riggers drops by the Targest amount, a reduction of $63 \%$ for both the primary and the alternate storage concepts.

The background dose rates are not currently wel1-defined and are considered to be conservative. A maximum steady-state dose rate of $0.75 \mathrm{mrem} / \mathrm{hr}$ was assigned to the receiving/shipping and transfer/discharge areas. A worker exposed to a $0.75 \mathrm{mrem} / \mathrm{hr}$ dose rate for 5 hours a day receives an annual dose of almost 0.94 rem. A lower background dose rate may be more appropriate. Table 19 indicates the average annual personnel dose estimates 
for the primary storage concept when the background dose in the receiving/ shipping and the transfer/discharge areas is $0.4 \mathrm{mrem} / \mathrm{hr}$. Table 20 illus trates the effect of a $0.4 \mathrm{mrem} / \mathrm{hr}$ background dose rate on average annual personnel doses for the alternate storage concept. The average annual dose to the crew supervisors in the receiving/shipping and transfer/discharge areas was reduced by 45\%; for the remaining personnel the reduction ranged from 0 to $16 \%$ for the primary storage concept and from 0 to $14 \%$ for the alternate storage concept.

AT though the MRS facility is designed for a throughput capacity of $3600 \mathrm{MTU} / \mathrm{yr}$, the actual amount of spent fuel received or shipped during any given year will likely be less. An estimate of the impact of a smaller (3000 MTU/yr) throughput on the occupational dose estimates is also shown in Tables 19 and 20. The dose estimates are based on the same number of personnel that were considered for the $3600 \mathrm{MTU} / \mathrm{yr}$ throughput, al though reduced staffing levels will likely accompany the lower throughput. As Tables 19 and 20 indicate, the average annual dose will be reduced by up to $14 \%$ for the primary storage concept and up to $17 \%$ for the alternate storage concept. 
SUMMARY AND CONCLUSIONS

The occupational dose estimates are based on the current conceptual design of the MRS facility and on shipping casks that are similar in design, a) though larger than the existing shipping casks. These dose estimates can best be used to indicate areas where improvements can be made in the facility design and in the transportation system that are expected to reduce the occupational dose.

For both crews (the receiving and storage crew and the other radiation worker crew), the personnel dose for all workers can be expected to be below the federal dose equivalent limit of $5 \mathrm{rem} / \mathrm{yr}$. However, as indicated, the dose estimates for certain personnel are greater than the $1.0 \mathrm{rem} / \mathrm{yr}$ design objective. The dose estimates for the receiving and storage crew indicate that the dose to the technicians, crane operators, riggers, millwrights, and storage area crew chief for both the primary and the alternate storage concepts will be above the $1.0 \mathrm{rem} / \mathrm{yr}$ design dose objective. The dose to the storage area inspector will also be above the design objective for the al ternate storage concept. The dose estimates for the other radiation worker crew indicate that the annual dose received by the crane maintenance technicians and the cold and remote maintenance technicians may be above the design objective. The dose to the remaining personnel will likely be below the design objective.

The dose rates received by members of the receiving and storage crew were substantially decreased when certain processes were considered to be remote and the distance between the worker and the source was subsequentiy increased. Lowering the background dose rate or assuming a smaller annual throughput will reduce the dose to the receiving and storage crew; however, the reduction is not adequate to reduce the personnel doses below $1.0 \mathrm{rem} / \mathrm{yr}$.

A combination of remote operations, the use of additional shielding, and additional personnel (or changes in procedures) appears to be necessary to reduce the worker dose below $1.0 \mathrm{rem} / \mathrm{yr}$. The processes most conducive to dose reduction by the inclusion of remote operations are the receipt, inspection, and unloading process and the shipment of the waste to the repository. These 
processes account for the largest fraction of the dose received by the technicians, the crane operators, the riggers and the millwrights. The dose to riggers could be reduced by $63 \%$ by using remote operations. Tasks that could conceivably be made at least partially remote include the removal or installation of the tiedowns, impact limiters, and personnel barriers from the shipping casks, the preparations for removing the shipping cask, the positioning of the cask lifting yoke, and the loosening of the bolts on the inner cask closure lid. These tasks contribute the largest amount of dose during the receiving and shipping processes.

The use of additional shielding will also serve to decrease personnel dose. Shielding placed in appropriate locations in the receiving/shipping and transfer/discharge areas will reduce the background dose rates to personnel who are waiting between process tasks. Shielding installed in the pickup trucks, cranes, and transport vehicles used in the storage area will reduce the annual dose received by the storage area crews.

Other methods can be used to decrease the personnel dose to the receiving and storage crew, such as changing procedures or using additional personnel for specific jobs. For example, these methods could be used to decrease the average dose to the crew chiefs at the storage area. The exposure time and estimated dose can be decreased by reducing the schedule for monitoring the storage casks or drywells that do not contain spent fuel, by not requiring the crew chiefs to remain in the storage facility the entire time the crew is there, or by providing additional storage area crew chiefs. These methods could also be effective for other personnel such as the crane operators, where the estimated task time exceeds the assumed work capacity.

The information used to obtain the dose estimates will need to be confirmed. Additional dose estimates should be made as the facility design is refined and as methods for reducing dose to an individual are incorporated. This is especially important as the design of the shipping cask progresses because of the large fraction of the dose obtained during the shipping cask handling process. These future analyses will provide a clearer indication of the personnel doses expected for the facility. 
TABLE 1. Receiving and Storage Crew ${ }^{(a)}$

\begin{tabular}{|c|c|c|c|c|}
\hline \multirow[b]{2}{*}{ Assignment } & \multicolumn{4}{|c|}{ Number of Personnel } \\
\hline & $\begin{array}{c}\text { Receiving/Shipping } \\
\text { Area }\end{array}$ & $\begin{array}{l}\text { Transfer/ } \\
\text { Discharge } \\
\text { Area } \\
\end{array}$ & $\begin{array}{c}\text { Storage } \\
\text { Area } \\
\end{array}$ & Total \\
\hline $\begin{array}{l}\text { Primary Storage Concept } \\
\text { Technicians } \\
\text { Crane/Transport Operators } \\
\text { Riggers } \\
\text { Miliwrights } \\
\text { Crew Supervisors - Receiving/Shipping } \\
\text { Crew Supervisors - Transfer/Discharge } \\
\text { Crew Supervisors - Storage Area } \\
\text { Inspector }\end{array}$ & $\begin{array}{r}61 \\
9 \\
26 \\
14 \\
8 \\
-- \\
-- \\
--\end{array}$ & $\begin{array}{r}16 \\
-- \\
-- \\
-- \\
-- \\
5 \\
-- \\
--\end{array}$ & $\begin{array}{r}2 \\
2 \\
-- \\
-- \\
-- \\
-- \\
1 \\
1\end{array}$ & $\begin{array}{r}79 \\
11 \\
26 \\
22 \\
8 \\
5 \\
1 \\
1\end{array}$ \\
\hline $\begin{array}{l}\text { Alternate Storage Concept } \\
\text { Techinicians } \\
\text { Crane/Transport Operators } \\
\text { Riggers } \\
\text { Millwrights } \\
\text { Crew Supervisors - Receiving/Shipping } \\
\text { Crew Supervisors - Transfer/Discharge } \\
\text { Crew Supervisors - Storage Area } \\
\text { Inspector }\end{array}$ & $\begin{array}{r}61 \\
9 \\
26 \\
14 \text { (+8 from site services) } \\
8 \\
-- \\
-- \\
--\end{array}$ & $\begin{array}{r}16 \\
-- \\
-- \\
-- \\
-- \\
5 \\
-- \\
--\end{array}$ & $\begin{array}{r}8 \\
8 \\
-- \\
-- \\
-- \\
-- \\
4 \\
4\end{array}$ & $\begin{array}{r}85 \\
17 \\
26 \\
22 \\
8 \\
5 \\
4 \\
4\end{array}$ \\
\hline
\end{tabular}

(a) From the Conceptual Design Report (The Ralph M. Parsons Company 1985a, Vol. I, Book II). 
TABLE 2. Exposure Rates at Various Distances from a SpentFuel Shipping Cask Received at the MRS Facility

\begin{tabular}{|c|c|c|c|}
\hline $\begin{array}{l}\text { Distance } \\
\text { from Cask } \\
(\mathrm{ft})\end{array}$ & $\begin{array}{l}\text { Exposure } \\
\text { Rate Due to }(a) \\
\text { General Field } \\
(m R / h r)\end{array}$ & $\begin{array}{c}\text { Exposure } \\
\text { Rate Due to }(b) \\
\text { Voids and Penetrations } \\
\text { in the Cask (mR/hr) }\end{array}$ & $\begin{array}{c}\text { Tota] Exposure } \\
\text { Rate from } \\
\text { Shipping Cask } \\
(\mathrm{mR} / \mathrm{hr})\end{array}$ \\
\hline Contact & 8.0 & 32 & 40 \\
\hline 2 & 6.0 & 9.0 & 15 \\
\hline 3 & 4.5 & 4.0 & 8.5 \\
\hline 4 & 4.0 & 2.2 & 6.2 \\
\hline 5 & 3.5 & 1.4 & 5.0 \\
\hline 6 & 3.0 & 1.0 & 4.0 \\
\hline 8 & 2.5 & 0.5 & 3.0 \\
\hline 10 & 2.2 & 0.3 & 2.5 \\
\hline 15 & 1.5 & 0.2 & 1.7 \\
\hline 20 & 1.0 & -- & 1.0 \\
\hline
\end{tabular}

(a) Exposure rates are from shielding calculations on a model of an NLI-1/2 cask containing two PWR spent-fuel assemblies using the computer code ISOSHLD (Engle, Greenborg, and Hendrickson 1966; Simmons et al. 1967). The source terms were based on the gamma source strengths given in the Conceptual Basis for Design Report (The Ralph M. Parsons Company 1985b) for PWR spent fuel, 33,000 MWD/MTU burnup and 10 years out of the reactor.

(b) Exposure rates vary with distance as $1 / r^{2}$. 
TABLE 3. Storage Area Capacities

\begin{tabular}{lccc} 
Waste Type & $\begin{array}{c}\text { Yearly Quantity } \\
(3,600 \mathrm{MTU} / \mathrm{yr})\end{array}$ & $\begin{array}{c}\text { Total } \\
\text { (15,000-MTU Facility })\end{array}$ \\
\cline { 1 - 2 } Primary Storage Concept - Number of Sealed Storage Casks & \\
\cline { 1 - 2 } Spent fuel & 272 & 1,131 \\
Nonfuel-bearing components & 107 & 440 \\
West Valley high-level waste & 12 & 60 \\
Onsite-generated waste & 33 & 129 \\
& 424 & 1,760
\end{tabular}

\begin{tabular}{lrr} 
Alternate Storage Concept - Number of Drywells & \\
\hline Spent fuel & 3,256 & 13,555 \\
Nonfuel-bearing components & 317 & 1,319 \\
West Valley high-level waste & 60 & 300 \\
Onsite-generated waste & 295 & 1,154 \\
& $\mathbf{3 , 9 2 8}$ & 16,328
\end{tabular}


TABLE 4. Receipt, Inspection, and Unloading of Shipping Casks (Preliminary Estimates)

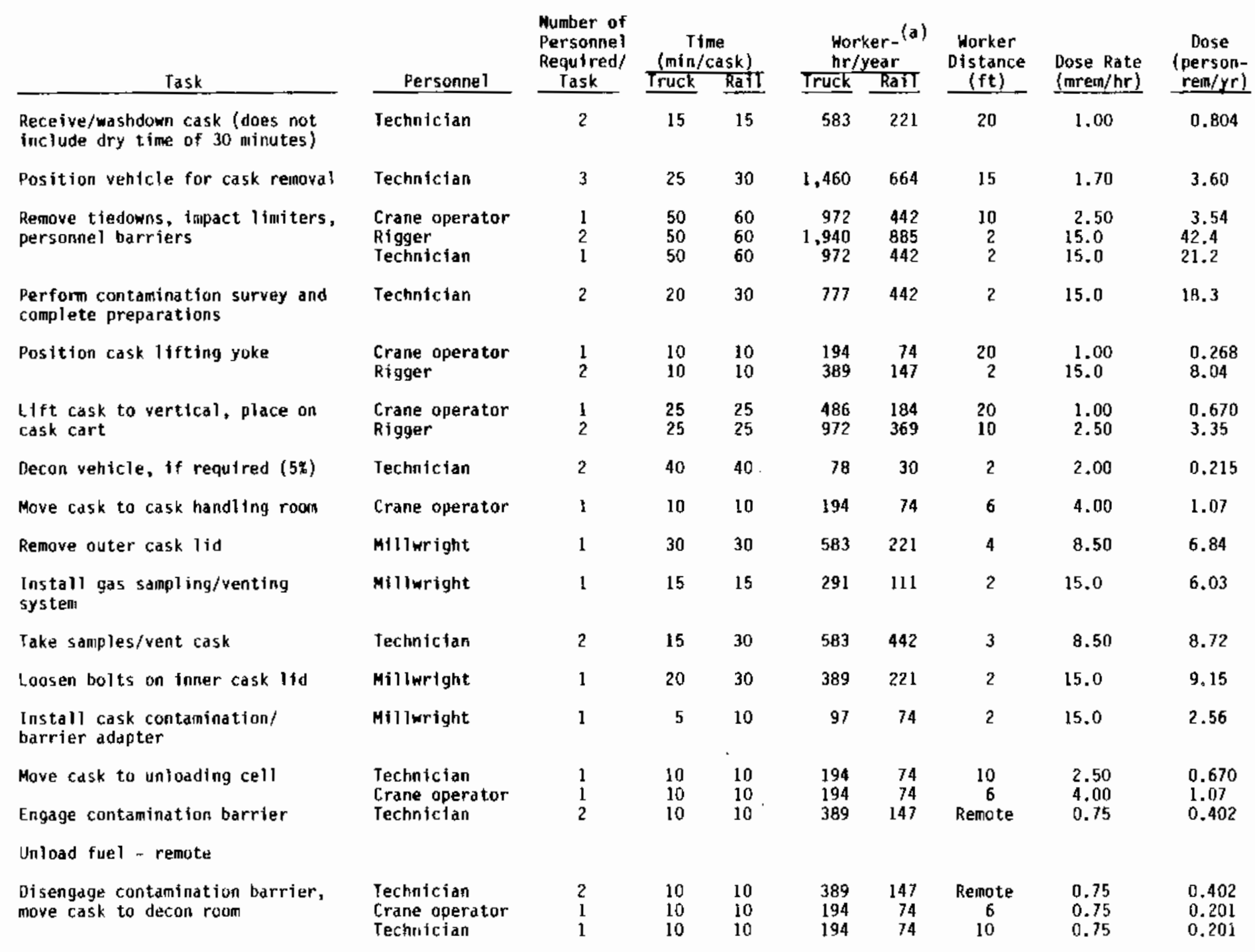

(a) Based on 442 rail casks/yr; 1166 truck casks/yr. 


\section{Table 4 (Contd)}

\begin{tabular}{|c|c|c|c|c|c|c|c|c|c|}
\hline Task & Personnel & $\begin{array}{l}\text { Number of } \\
\text { Personnel } \\
\text { Requitred/ } \\
\text { Task }\end{array}$ & \multicolumn{2}{|c|}{$\underset{(m \mid n / \text { cask })}{\text { Time }}$} & \multicolumn{2}{|c|}{$\begin{array}{l}\text { Horker- (a) } \\
\text { hr/year }\end{array}$} & $\begin{array}{c}\text { Worker } \\
\text { Bistance } \\
(\mathrm{ft}) \\
\end{array}$ & $\begin{array}{l}\text { Dose Rate } \\
\text { (mren/hr) }\end{array}$ & $\begin{array}{l}\text { Dose } \\
\text { (person } \\
\text { rem/yr }\end{array}$ \\
\hline $\begin{array}{l}\text { Remove contamination barrier } \\
\text { adapter, dpply bolts and outer } \\
\text { lid cover. }\end{array}$ & Miliwright. & 1 & 55 & 75 & $1,0 \% 0$ & 553 & 2 & 0.75 & 1.22 \\
\hline Perforn contaninatiun survey & Techntcian & 1 & 30 & 40 & 583 & 295 & 2 & 0.75 & 0.658 \\
\hline Decon cask, if required (10\%) & Technician & 3 & 40 & 40 & 233 & 88 & 2 & 1.00 & 0.322 \\
\hline Move cask to transport vehicle & $\begin{array}{l}\text { Crane operator } \\
\text { Rígger }\end{array}$ & $\frac{1}{2}$ & $\begin{array}{l}35 \\
35\end{array}$ & $\begin{array}{l}35 \\
35\end{array}$ & $\begin{array}{r}680 \\
1,360\end{array}$ & $\begin{array}{l}258 \\
516\end{array}$ & $\begin{array}{r}20 \\
2\end{array}$ & $\begin{array}{l}0.75 \\
0.75\end{array}$ & $\begin{array}{l}0.704 \\
1.41\end{array}$ \\
\hline Install tiedowns, etc. & $\begin{array}{l}\text { Crane operator } \\
\text { Rigger } \\
\text { Technician }\end{array}$ & $\begin{array}{l}1 \\
2 \\
1\end{array}$ & $\begin{array}{l}45 \\
45 \\
45\end{array}$ & $\begin{array}{l}60 \\
60 \\
60\end{array}$ & $\begin{array}{r}874 \\
1,750 \\
874 \\
\end{array}$ & $\begin{array}{l}442 \\
885 \\
442 \\
\end{array}$ & $\begin{array}{r}10 \\
2 \\
2\end{array}$ & $\begin{array}{l}0.75 \\
0.75 \\
0.75\end{array}$ & $\begin{array}{l}0.988 \\
1.98 \\
0.988 \\
\end{array}$ \\
\hline & & & & & 19,900 & 9,110 & & & 148. \\
\hline
\end{tabular}


TABLE 5. Transfer of Waste Canisters from Process Cells into Storage Casks (Preliminary Estimates)

\begin{tabular}{|c|c|c|c|c|c|c|c|c|}
\hline Task & Personfiel & $\begin{array}{l}\text { Number of } \\
\text { Personnel } \\
\text { Required/ } \\
\text { Task } \\
\end{array}$ & $\begin{array}{c}\text { Time } \\
\text { (min/cask) } \\
\end{array}$ & $\begin{array}{l}\text { Casks/ } \\
\text { year }\end{array}$ & $\begin{array}{l}\text { Morker- } \\
\text { hr/year }\end{array}$ & $\begin{array}{c}\text { Horker } \\
\text { Distance } \\
\text { (ft) } \\
\end{array}$ & $\begin{array}{l}\text { Dose Rate } \\
\text { (mrem/hr) }\end{array}$ & $\begin{array}{c}\text { Dose } \\
\text { (person- } \\
\text { rem/yr) }\end{array}$ \\
\hline Move cask to unloading room & $\begin{array}{l}\text { Transport Oper. } \\
\text { Technictan }\end{array}$ & $\begin{array}{l}1 \\
1\end{array}$ & $\begin{array}{l}15 \\
15\end{array}$ & $\begin{array}{l}424 \\
424\end{array}$ & $\begin{array}{l}106 \\
106\end{array}$ & 12.5 & $\begin{array}{l}0.75 \\
0.75\end{array}$ & $\begin{array}{l}0.080 \\
0.080\end{array}$ \\
\hline $\begin{array}{l}\text { Install contamination barrier and } \\
\text { shield ring. move into corridor }\end{array}$ & $\begin{array}{l}\text { Transport 0per. } \\
\text { Techntcian } \\
\text { Technician }\end{array}$ & $\begin{array}{l}1 \\
1 \\
1\end{array}$ & $\begin{array}{l}15 \\
15 \\
15\end{array}$ & $\begin{array}{l}424 \\
424 \\
424\end{array}$ & $\begin{array}{l}106 \\
106 \\
106\end{array}$ & $\begin{array}{l}12.5 \\
3 \\
8\end{array}$ & $\begin{array}{l}0.75 \\
0.75 \\
0.75\end{array}$ & $\begin{array}{l}0.080 \\
0.080 \\
0.080\end{array}$ \\
\hline $\begin{array}{l}\text { Engage contamination barrier, } \\
\text { cluse shadow shield }\end{array}$ & Technician & 2 & 10 & 424 & 141 & Remote & 0.75 & 0.106 \\
\hline \multicolumn{9}{|l|}{ Loadout fuel - remote } \\
\hline $\begin{array}{l}\text { O1sengage contamination barrier. } \\
\text { move cask into corridor }\end{array}$ & $\begin{array}{l}\text { Technicianl } \\
\text { Transport Oper. } \\
\text { Technician }\end{array}$ & $\begin{array}{l}1 \\
1 \\
1\end{array}$ & $\begin{array}{l}10 \\
10 \\
10\end{array}$ & $\begin{array}{l}424 \\
424 \\
424\end{array}$ & $\begin{array}{l}71 \\
71 \\
71\end{array}$ & $\begin{array}{l}\text { Remote } \\
12.5 \\
8\end{array}$ & $\begin{array}{l}0.75 \\
2.00 \\
3.00\end{array}$ & $\begin{array}{l}0.053 \\
0.141 \\
0.212\end{array}$ \\
\hline Survey of cask top for contamination & Technician & 2 & 10 & 424 & 141 & 2 & 6.00 & 0.848 \\
\hline Decon if necessary (10x) & Technician & 2 & 30 & 42 & 42 & 3 & 5.00 & 0.210 \\
\hline $\begin{array}{l}\text { Remove plug } 11 \mathrm{ft} \text { ing eyes and } \\
\text { lower cask cover }\end{array}$ & $\begin{array}{l}\text { Technictan } \\
\text { Technictan } \\
\text { Crane Operator }\end{array}$ & $\begin{array}{l}1 \\
1 \\
1\end{array}$ & $\begin{array}{l}10 \\
10 \\
10\end{array}$ & $\begin{array}{l}424 \\
424 \\
424\end{array}$ & $\begin{array}{l}71 \\
71 \\
71\end{array}$ & $\begin{array}{r}2 \\
8 \\
20\end{array}$ & $\begin{array}{l}6.00 \\
3.00 \\
1.00\end{array}$ & $\begin{array}{l}0.424 \\
0.212 \\
0.071\end{array}$ \\
\hline Set up reiding equipment & Technictan & $\underline{2}$ & !n & 424 & 142 & 2 & 2.00 & 0.282 \\
\hline Perform remote welding & Technictan & 2 & 60 & 424 & 848 & 20 & 0.75 & 0.636 \\
\hline $\begin{array}{l}\text { Remove welder and inspect and } \\
\text { test the weld }\end{array}$ & Technictan & 2 & 45 & 424 & 636 & 2 & 2.00 & 1.27 \\
\hline \multirow[t]{2}{*}{ Pressure check cask interior } & Techntctan & 2 & $\begin{array}{l}10 \\
30 \\
15\end{array}$ & $\begin{array}{l}424 \\
424 \\
424\end{array}$ & $\begin{array}{l}141 \\
424 \\
212 \\
\end{array}$ & $\begin{array}{l}2 \\
5 \\
2\end{array}$ & $\begin{array}{l}2.00 \\
1.50 \\
2.00\end{array}$ & $\begin{array}{l}0.283 \\
0.636 \\
0.424 \\
\end{array}$ \\
\hline & & & & & 3,680 & & & 6.21 \\
\hline
\end{tabular}


TABLE 6. Emplacement of Storage Casks in the Storage Area (Preliminary Estimates)

\begin{tabular}{|c|c|c|c|c|c|c|c|}
\hline Task & Persounel & $\begin{array}{l}\text { Munber of } \\
\text { Personne1 } \\
\text { Required/ } \\
\text { Iask } \\
\end{array}$ & $\begin{array}{c}\text { Time } \\
(\min / \mathrm{cdsk}) \\
\end{array}$ & $\begin{array}{l}\text { Casks/ } \\
\text { year }\end{array}$ & $\begin{array}{l}\text { Worker } \\
\text { hr/year }\end{array}$ & $\begin{array}{l}\text { Dose Rate } \\
\text { (mrem/hr) }\end{array}$ & $\begin{array}{c}\text { Dose } \\
\text { (person- } \\
\text { rem/yr) }\end{array}$ \\
\hline Drive cask to storage area & Transport Oper. & l & 30 & 424 & 212 & 2.00 & 0.424 \\
\hline Drive into storage ared & $\begin{array}{l}\text { Crane Operator } \\
\text { Crew Chief } \\
\text { Technictan-1 } \\
\text { Technlctan-2 }\end{array}$ & $\begin{array}{l}1 \\
1 \\
1 \\
1\end{array}$ & $\begin{array}{l}2.5 \\
2.5 \\
2.5 \\
2.5\end{array}$ & $\begin{array}{l}424 \\
424 \\
424 \\
242\end{array}$ & $\begin{array}{l}18 \\
18 \\
18 \\
18\end{array}$ & $\begin{array}{l}0.10 \\
0.10 \\
0.10 \\
0.10\end{array}$ & $\begin{array}{l}0.002 \\
0.002 \\
0.002 \\
0.002\end{array}$ \\
\hline Unload cask & $\begin{array}{l}\text { Transport 0per. } \\
\text { Crane Operator } \\
\text { Techntctan-1 } \\
\text { Crew Chief } \\
\text { Techntcian-2 }\end{array}$ & $\begin{array}{l}1 \\
1 \\
1 \\
1 \\
1\end{array}$ & $\begin{array}{l}15 \\
25 \\
25 \\
25 \\
15\end{array}$ & $\begin{array}{l}424 \\
424 \\
424 \\
424 \\
424\end{array}$ & $\begin{array}{l}106 \\
176 \\
176 \\
176 \\
106\end{array}$ & $\begin{array}{l}5.40 \\
5.10 \\
6.50 \\
6.50 \\
5.40\end{array}$ & $\begin{array}{l}0.572 \\
0.901 \\
1.15 \\
1.15 \\
0.572\end{array}$ \\
\hline $\begin{array}{l}\text { Drive transporter out of storage } \\
\text { area }\end{array}$ & Transport Oper. & 1 & 30 & 424 & 212 & 0.10 & 0.021 \\
\hline Hookup instrumentation & Technician-2 & 1 & 25 & 424 & 176 & 9.00 & 1.59 \\
\hline Drive out of storage area & $\begin{array}{l}\text { Crane 0perator } \\
\text { Crew Chief } \\
\text { Techntcian-1 } \\
\text { Technician-2 }\end{array}$ & $\begin{array}{l}1 \\
1 \\
1 \\
1\end{array}$ & $\begin{array}{l}2.5 \\
2.5 \\
2.5 \\
2.5\end{array}$ & $\begin{array}{l}424 \\
424 \\
424 \\
424\end{array}$ & $\begin{array}{l}18 \\
18 \\
18 \\
18\end{array}$ & $\begin{array}{l}0.10 \\
0.10 \\
0.10 \\
0.10\end{array}$ & $\begin{array}{l}0.002 \\
0.002 \\
0.002 \\
0.002\end{array}$ \\
\hline \multirow[t]{2}{*}{ Move crane (every other cask) } & $\begin{array}{l}\text { Crane 0perator } \\
\text { Technician-1 } \\
\text { Crew Chlef }\end{array}$ & $\begin{array}{l}1 \\
1 \\
1\end{array}$ & $\begin{array}{l}15 \\
15 \\
15\end{array}$ & $\begin{array}{l}212 \\
212 \\
212\end{array}$ & $\begin{array}{l}53 \\
53 \\
53 \\
\end{array}$ & $\begin{array}{l}5.10 \\
5.10 \\
5.10\end{array}$ & $\begin{array}{l}0.270 \\
0.270 \\
0.270 \\
\end{array}$ \\
\hline & & & & & 1,640 & & 7.20 \\
\hline
\end{tabular}


TABLE 7. Surveillance and Inspection of Storage Casks in the Storage Area (Preliminary Estimates)

\begin{tabular}{|c|c|c|c|c|c|c|c|}
\hline Task & Personnel & $\begin{array}{c}\text { Mumber of } \\
\text { Personnel } \\
\text { Required/ } \\
\text { Task } \\
\end{array}$ & $\begin{array}{c}\text { Time } \\
\text { (min/cask) }\end{array}$ & Casks/yr & $\begin{array}{l}\text { Horker- } \\
\text { hr/year }\end{array}$ & $\begin{array}{l}\text { Dose Rate } \\
\text { (mrem/hr) }\end{array}$ & $\begin{array}{c}\text { Dose } \\
\text { (person- } \\
\text { rem/yr) }\end{array}$ \\
\hline
\end{tabular}

\section{Monitoring}

Obtain gas sample, temperature

Technician-1
Technician-2

Cres Chief

Technictan-1,2

1

Pressure decay test (2\%)

1

$$
\begin{aligned}
& 2 \\
& 1.5 \\
& 0.5
\end{aligned}
$$

1,760

1,760
1,760

1,760

44

44
15

$\omega$

Accountability

Inspect

Record

Orive

Instrument readings

Inspector
Technician-1
Technician-2
Technician-1
Inspector

2

35
35

$\begin{array}{rr}8.5 & 0.499 \\ 11.5 & 0.506 \\ 10.2 & 0.150 \\ 8.5 & 0.499 \\ 11.5 & 0.134 \\ 9.6 & 0.336\end{array}$

inspector

1,760
1,760
1,760
1,760
1,760

6.0

$0.52 B$

E. 0

$0.52 \mathrm{~B}$

9.0

0.792

11.5

0.675

59
59

59

11.5

0.675

609

5.32 
TABLE 8. Retrieval of Storage Casks from the Storage Area (Preliminary Estimates)

\begin{tabular}{l} 
Personnel \\
\hline Crane operator \\
Crew chief \\
Technician-1 \\
Technician-2
\end{tabular}

Number of

Task

Required/

Drive into storage area

Task.

\begin{tabular}{c} 
Tíne \\
(min/cask) \\
\hline
\end{tabular}

Casks/

Worker-

1

Techntcian-

Drive transporter into storage area

Inspect cask

Remove instrumentation

Load cask onto transporter

Transport oper.

Technician-1

Crew chief

Technician-1

Crane operator

Transport 0per.

Technician-2

Crew chief

Technician-1

Move crane (every other cask)

Crane operator

Technician-1

Crew chief

$\begin{array}{lll}2.5 & 424 & 18 \\ 2.5 & 424 & 18 \\ 2.5 & 424 & 18 \\ 2.5 & 424 & 18\end{array}$

Dose Rate

(mrem/hr)

Oose

1

1
1

2.5
2.5

47.4

212

30

5
5

424

424

35
35

424

35

5

424

424
424

424

424
424

0.10
0.10
0.10

0.10
0.10

0.002

0.002

$0.10 \quad 0.002$

0.10

0.021

9.00

9.00

0.318
0.318

9.00

0.318

5.40

5.10

6.50

6.50

5.40

0.954

0.901

1.15

1.15

0.763

Transport 0per.

Drive cask to RaH bullding

Drive out of storage area

\section{Crane operator}

Crew chief

Technictan-1

Technician-2

212

5.10

5.10

0.270

$212 \quad 53$

5.10

0.270

2.00

0.424

30

424

212

0.10

0.10

0.10

0.002

2.5
2.5
2.5
2.5

424
424

18
18

18

0.10

0.002

0.002

1,680

7.14 
TABLE 9. Transfer of Waste Canisters from Storage Casks into Process Cells (Preliminary Estimates)

\begin{tabular}{|c|c|c|c|c|c|c|c|c|}
\hline Task & Personnel & $\begin{array}{l}\text { Nunber of } \\
\text { Personnel } \\
\text { Required/ } \\
\text { Task } \\
\end{array}$ & $\begin{array}{c}\text { Tink } \\
\text { (min/cask) } \\
\end{array}$ & $\begin{array}{l}\text { Casks/ } \\
\text { year } \\
\end{array}$ & $\begin{array}{l}\text { Horker- } \\
\text { hr/year }\end{array}$ & $\begin{array}{l}\text { Distance } \\
(\mathrm{ft}) \\
\end{array}$ & $\begin{array}{c}\text { Worker } \\
\text { Dose Rate } \\
\text { (arem/hr) }\end{array}$ & $\begin{array}{l}\text { Dose } \\
\text { (person- } \\
\text { rem/yr) } \\
\end{array}$ \\
\hline Set up weld cutting equipment & Techniclan & 2 & 15 & 424 & 212 & 2 & 2.00 & 0.424 \\
\hline Perform remote weld cutting & Technician & 2 & 65 & 424 & 918 & 20 & 0.75 & 0.690 \\
\hline Remove weld cutting equipment & Techntcian & 2 & 10 & 424 & 142 & 2 & 2.00 & 0.282 \\
\hline $\begin{array}{l}\text { Remove cover, attach plug } \\
\text { lifting eyes }\end{array}$ & $\begin{array}{l}\text { Crane operator } \\
\text { Technician } \\
\text { Technician }\end{array}$ & $\begin{array}{l}1 \\
1 \\
1\end{array}$ & $\begin{array}{l}10 \\
30 \\
20\end{array}$ & $\begin{array}{l}424 \\
424 \\
424\end{array}$ & $\begin{array}{r}71 \\
212 \\
141\end{array}$ & $\begin{array}{r}20 \\
2 \\
8\end{array}$ & $\begin{array}{l}1.00 \\
6.00 \\
3.00\end{array}$ & $\begin{array}{l}0.071 \\
1.27 \\
0.424\end{array}$ \\
\hline $\begin{array}{l}\text { Move cask, position under exit } \\
\text { port }\end{array}$ & $\begin{array}{l}\text { Transport 0per. } \\
\text { Technician }\end{array}$ & 1 & $\begin{array}{l}10 \\
10\end{array}$ & $\begin{array}{l}424 \\
424\end{array}$ & $\begin{array}{l}71 \\
71\end{array}$ & $\frac{12.5}{8}$ & $\begin{array}{l}2.00 \\
3.00\end{array}$ & $\begin{array}{l}0.141 \\
0.212\end{array}$ \\
\hline $\begin{array}{l}\text { Engage contamination barrier } \\
\text { Load out fuel - remote }\end{array}$ & Techniclan & 1 & 10 & 424 & 71 & Reinote & 0.75 & 0.053 \\
\hline $\begin{array}{l}\text { Disengage contamination barrier. } \\
\text { open shadow shleld }\end{array}$ & Technictan & 2 & 15 & 424 & 212 & Remote & 0.75 & 0.159 \\
\hline Move cask Into corridor & $\begin{array}{l}\text { Transport Oper. } \\
\text { Techntcian }\end{array}$ & $\begin{array}{l}1 \\
1\end{array}$ & $\begin{array}{l}10 \\
10\end{array}$ & $\begin{array}{l}424 \\
424\end{array}$ & 71 & 12.5 & $\begin{array}{l}0.75 \\
0.75\end{array}$ & $\begin{array}{l}0.053 \\
0.053\end{array}$ \\
\hline Survey of cask top for contamination & Technician & 2 & 10 & 424 & 141 & 2 & 0.75 & 0.106 \\
\hline Decon cask top if necessary (10x) & Technician & 2 & 30 & 42 & 42 & 2 & 1.00 & 0.042 \\
\hline \multirow[t]{2}{*}{$\begin{array}{l}\text { Decon cask interior if necessary } \\
\text { (2‡) }\end{array}$} & Technictan & 2 & 3D & 9 & 9 & 2 & 1.00 & 0,009 \\
\hline & & & & & 2,455 & & & 3.99 \\
\hline
\end{tabular}


TABLE 10. Loading and Shipment of Repository Overpacks (R0) and Shipping Casks for Repository Overpacks (SCFRO) (Preliminary Estimates)

\begin{tabular}{|c|c|c|c|c|c|c|c|}
\hline Task & Personnel & $\begin{array}{l}\text { Number of } \\
\text { Personnel } \\
\text { Requitred/ } \\
\text { Task } \\
\end{array}$ & $\begin{array}{c}\text { Time } \\
(m \mid n / c a s k)\end{array}$ & $\begin{array}{l}\text { Norker- }(a) \\
\text { hr/year }\end{array}$ & $\begin{array}{c}\begin{array}{c}\text { Worker } \\
\text { Distance } \\
\text { (ft) }\end{array} \\
\end{array}$ & $\begin{array}{l}\text { Dose Rate } \\
\text { (arrem } / \mathrm{hr} \text { ) }\end{array}$ & $\begin{array}{l}\text { Dose } \\
\text { (person- } \\
\text { rem/yr) } \\
\end{array}$ \\
\hline $\begin{array}{l}\text { Receive/washdown R0 (does not } \\
\text { include dry time of } 30 \text { milnutes) }\end{array}$ & Technictan & 2 & 15 & 660 & 20 & 0.75 & 0.495 \\
\hline $\begin{array}{l}\text { Recelve/washdown SCFRO (does not } \\
\text { include dry time of } 30 \text { ininutes) }\end{array}$ & Technictan & 2 & 15 & 660 & 20 & 0.75 & 0.495 \\
\hline Position vehicle for Ro renoval & Technician & 3 & 20 & 1,320 & 15 & 0.75 & 0.989 \\
\hline Position vehicle for SCFRO removal & Techntcian & $\mathbf{3}$ & 20 & 1,320 & 15 & 0.75 & 0.989 \\
\hline $\begin{array}{l}\text { Remove tiedowns, impact } 1 \text { imiters, } \\
\text { and shipping restraints - R0 }\end{array}$ & $\begin{array}{l}\text { Crane operator } \\
\text { Rigger } \\
\text { Technician }\end{array}$ & $\begin{array}{l}1 \\
2 \\
1\end{array}$ & $\begin{array}{l}30 \\
30 \\
30\end{array}$ & $\begin{array}{r}660 \\
1,320 \\
660\end{array}$ & $\begin{array}{r}10 \\
2 \\
2\end{array}$ & $\begin{array}{l}0.75 \\
0.75 \\
0.75\end{array}$ & $\begin{array}{l}0.495 \\
0.989 \\
0.495\end{array}$ \\
\hline $\begin{array}{l}\text { Reinove tiedowns, impact } 1 \text { 1miters, } \\
\text { personnel barriers - SCFRO }\end{array}$ & $\begin{array}{l}\text { Crane operator } \\
\text { Rigger } \\
\text { Techntcian }\end{array}$ & $\begin{array}{l}1 \\
2 \\
1\end{array}$ & $\begin{array}{l}60 \\
60 \\
60\end{array}$ & $\begin{array}{l}1,320 \\
2,640 \\
1,320\end{array}$ & $\begin{array}{r}10 \\
2 \\
2\end{array}$ & $\begin{array}{l}0.75 \\
0.75 \\
0.75\end{array}$ & $\begin{array}{l}0.989 \\
1.98 \\
0.989\end{array}$ \\
\hline Perform contamination survey SCFRO & Technician & 1 & 30 & 660 & 2 & 0.75 & 0.495 \\
\hline $\begin{array}{l}\text { Place cask adapter and Ro on a cask } \\
\text { cart }\end{array}$ & $\begin{array}{l}\text { Crane operator } \\
\text { Rigger }\end{array}$ & $\frac{1}{2}$ & $\begin{array}{l}65 \\
65\end{array}$ & $\begin{array}{l}1,430 \\
2,860\end{array}$ & $\begin{array}{l}20 \\
10\end{array}$ & $\begin{array}{l}0.75 \\
0.75\end{array}$ & $\begin{array}{l}1.07 \\
2.14\end{array}$ \\
\hline Move $R 0$ into unloading room & Crane operator & 1 & 10 & 220 & 6 & 0.75 & 0.165 \\
\hline $\begin{array}{l}\text { Install contamination barrier } \\
\text { adapter }\end{array}$ & millwright & 1 & 10 & 220 & 2 & 0.75 & 0.165 \\
\hline $\begin{array}{l}\text { Engage contamination barrier } \\
\text { Unload overpack - remote }\end{array}$ & Technician & 2 & 40 & 1.760 & Remote & 0.75 & 1.32 \\
\hline $\begin{array}{l}\text { Open shield door } \\
\text { Disengage contamination barrier } \\
\text { Move cask cart with R0 cask } \\
\text { adapter to receiving area- } \\
\text { remove cask adapter, survey }\end{array}$ & $\begin{array}{l}\text { Crane operator } \\
\text { Crane operator } \\
\text { Millwright } \\
\text { Jechnician } \\
\text { Rigger }\end{array}$ & $\begin{array}{l}1 \\
1 \\
1 \\
2 \\
1\end{array}$ & $\begin{array}{l}10 \\
20 \\
10 \\
65 \\
20\end{array}$ & $\begin{array}{r}220 \\
440 \\
220 \\
2,860 \\
440\end{array}$ & $\begin{array}{r}6 \\
10 \\
2 \\
2 \\
2\end{array}$ & $\begin{array}{l}0.75 \\
0.75 \\
0.75 \\
0.75 \\
0.75\end{array}$ & $\begin{array}{l}0.165 \\
0.330 \\
0.165 \\
2.14 \\
0.330\end{array}$ \\
\hline $\begin{array}{l}\text { Decon cask adapter if required } \\
\text { (10q) }\end{array}$ & Technictan & 2 & 30 & 132 & 2 & 1.00 & 0.132 \\
\hline
\end{tabular}

(a) Based on 1319 SCFRO sent annually to the repository. 
Table 10 (Contd)

\begin{tabular}{|c|c|c|c|c|c|c|c|}
\hline Task & Personnel & $\begin{array}{l}\text { Nuniber of } \\
\text { Persormel } \\
\text { Required/ } \\
\text { Iask } \\
\end{array}$ & $\begin{array}{c}\begin{array}{c}\text { Time } \\
\text { (min/cask) }\end{array} \\
\end{array}$ & $\begin{array}{l}\text { Horker-(a) } \\
\text { hr/year }\end{array}$ & $\begin{array}{c}\text { Morker } \\
\text { Distance } \\
\text { (ft) } \\
\end{array}$ & $\begin{array}{l}\text { Dose Rate } \\
\text { (mren/ hr) }\end{array}$ & $\begin{array}{c}\text { Oose } \\
\text { (person- } \\
\text { rem/yr) }\end{array}$ \\
\hline Move SCFR0 to cask cart & $\begin{array}{l}\text { Crane operator } \\
\text { Rigger } \\
\text { Rigger }\end{array}$ & $\begin{array}{l}1 \\
2 \\
2\end{array}$ & $\begin{array}{l}35 \\
10 \\
25\end{array}$ & $\begin{array}{r}769 \\
440 \\
1,100\end{array}$ & $\begin{array}{r}20 \\
2 \\
10\end{array}$ & $\begin{array}{l}0.75 \\
0.75 \\
0.75\end{array}$ & $\begin{array}{l}0.577 \\
0.330 \\
0.824\end{array}$ \\
\hline $\begin{array}{l}\text { Remove outer lid, } \\
\text { loosen bolts on inner lid }\end{array}$ & Millwright & 1 & 30 & 660 & 2 & 0.75 & 0.495 \\
\hline \multirow{2}{*}{$\begin{array}{l}\text { Move to cask handling and decon } \\
\text { rown } \\
\text { Install contamination barrier } \\
\text { adapter }\end{array}$} & Crane operator & 1 & 10 & 220 & 6 & 0.75 & 0.165 \\
\hline & Mfliwright & 1 & 10 & 220 & 2 & 0.75 & 0.165 \\
\hline Move to cask unloading room & $\begin{array}{l}\text { Crane operator } \\
\text { Technician }\end{array}$ & $\begin{array}{l}1 \\
1\end{array}$ & $\begin{array}{l}10 \\
10\end{array}$ & $\begin{array}{l}220 \\
220\end{array}$ & $\begin{array}{r}6 \\
10\end{array}$ & $\begin{array}{l}0.75 \\
0.75\end{array}$ & $\begin{array}{l}0.165 \\
0.165\end{array}$ \\
\hline Engage contanination barrier & Technician & 2 & 10 & 440 & Remote & 0.75 & 0.330 \\
\hline \multicolumn{8}{|l|}{ Load RO Into SCFRO - remote } \\
\hline Disengage cuntamination barrier & Technician & 2 & 10 & 440 & Remote & 0.75 & 0.330 \\
\hline Move cask to decon roum & $\begin{array}{l}\text { Technician } \\
\text { Crane operator }\end{array}$ & 1 & $\begin{array}{l}10 \\
10\end{array}$ & $\begin{array}{l}220 \\
220\end{array}$ & $\begin{array}{r}10 \\
6\end{array}$ & $\begin{array}{l}2.50 \\
4.00\end{array}$ & $\begin{array}{l}0.550 \\
0.879\end{array}$ \\
\hline Remove barrfer adapter & Millwright & 1 & 15 & 330 & 2 & 15.0 & 4.95 \\
\hline $\begin{array}{l}\text { Apply bolts } \\
\text { and outer IId cover }\end{array}$ & $\begin{array}{l}\text { Millwright } \\
\text { Miliwright }\end{array}$ & $\begin{array}{l}1 \\
1\end{array}$ & $\begin{array}{l}30 \\
25\end{array}$ & $\begin{array}{l}660 \\
550\end{array}$ & 2 & $\begin{array}{l}15.0 \\
8.50\end{array}$ & $\begin{array}{l}9.89 \\
4.57\end{array}$ \\
\hline Perform contamination survey & Technician & 1 & 40 & 879 & 2 & 15.0 & 13.2 \\
\hline Decon cask, if requtred (10\%) & Techntctan & 3 & 40 & 264 & 2 & 15.0 & 3.96 \\
\hline Move cask to transport vehicle & Crane operator & 1 & 10 & 220 & 6 & 4.00 & 0.879 \\
\hline Place SCFRO onto transport vehicle & $\begin{array}{l}\text { Crane operator } \\
\text { R1gger } \\
\text { R1gger }\end{array}$ & $\begin{array}{l}1 \\
2 \\
2\end{array}$ & $\begin{array}{l}35 \\
10 \\
25\end{array}$ & $\begin{array}{r}769 \\
440 \\
1.100\end{array}$ & $\begin{array}{r}20 \\
2 \\
10\end{array}$ & $\begin{array}{c}1.00 \\
15.0 \\
2.50\end{array}$ & $\begin{array}{l}0.769 \\
6.60 \\
2.75\end{array}$ \\
\hline $\begin{array}{l}\text { Install tiedowns, impact limiters, } \\
\text { and personnel barriers }\end{array}$ & $\begin{array}{l}\text { Rigger } \\
\text { Crane operator } \\
\text { Technician }\end{array}$ & $\begin{array}{l}2 \\
1 \\
1\end{array}$ & $\begin{array}{l}60 \\
60 \\
60\end{array}$ & $\begin{array}{l}2,640 \\
1,320 \\
1,320\end{array}$ & $\begin{array}{r}2 \\
10 \\
2\end{array}$ & $\begin{array}{l}15.0 \\
2.50 \\
15.0\end{array}$ & $\begin{array}{c}39.6 \\
3.30 \\
19.8\end{array}$ \\
\hline \multirow[t]{2}{*}{ Complete preparations for release } & Techrician & 2 & 30 & 1,320 & 4 & 6.20 & 8.18 \\
\hline & & & & 40,300 & & & 141. \\
\hline
\end{tabular}


TABLE 11. Summary of Task Dose from Spent Fuel Receipt, Storage and Shipment Operations - Primary Storage Concept

(Preliminary Estimates)

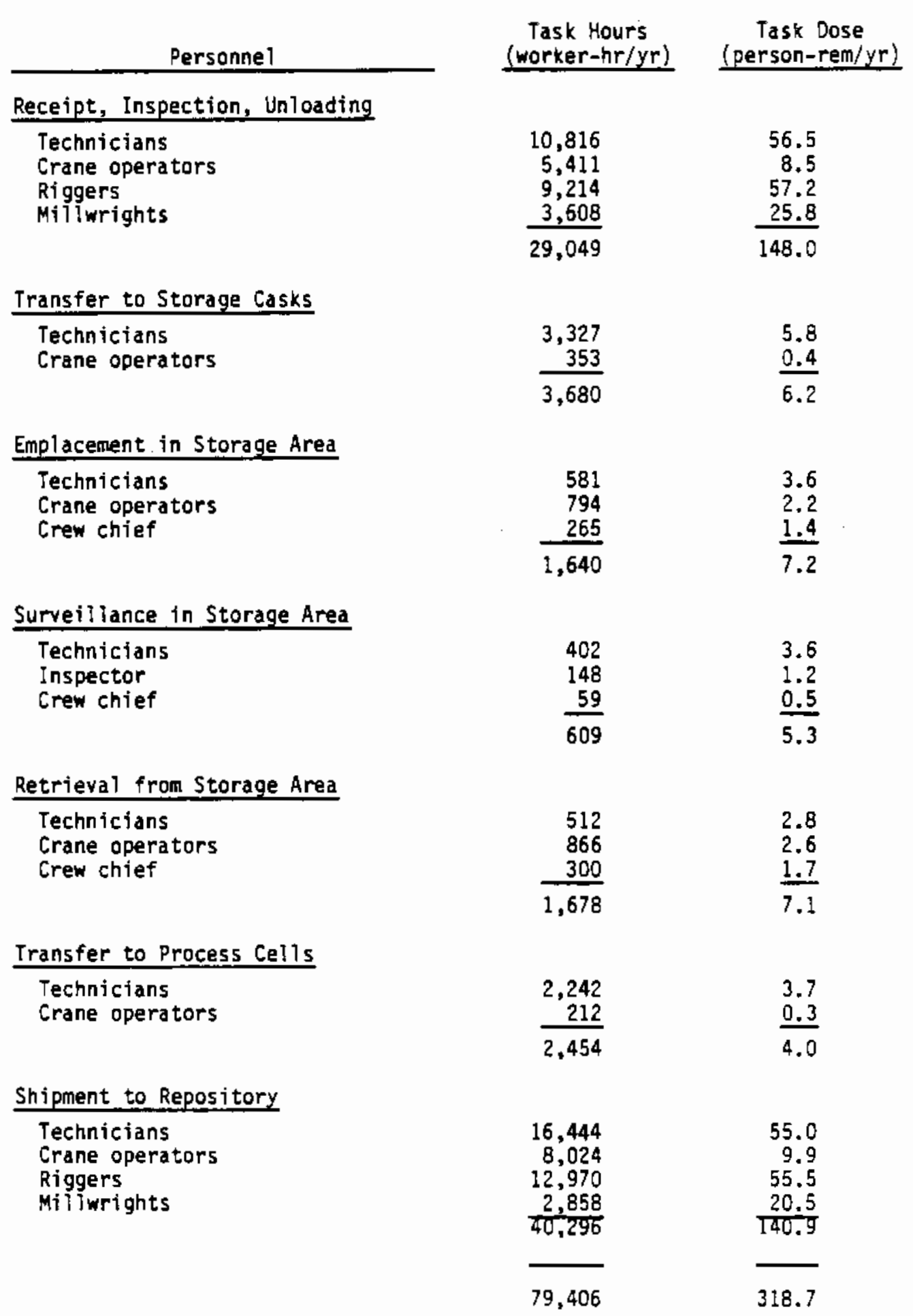


TABLE 12. Annual Dose to the Receiving and Storage Crew - Primary Storage Concept (Preliminary Estimates)

\begin{tabular}{|c|c|c|c|c|c|c|c|}
\hline Personnel & $\begin{array}{l}\text { Number of } \\
\text { Personnel } \\
\end{array}$ & $\begin{array}{c}\text { Task } \\
\text { (worker-hr) }\end{array}$ & $\begin{array}{l}\text { Task Dose } \\
\text { (person- } \\
\text { rem/yr) }\end{array}$ & $\begin{array}{c}\text { Zone } \\
\text { Background } \\
\text { Dose } \\
\text { (person- } \\
\text { remfyr } \\
\end{array}$ & $\begin{array}{l}\text { Mon-Zone } \\
\text { Background } \\
\text { Dose } \\
\text { (person- } \\
\text { rem/yr) }\end{array}$ & $\begin{array}{l}\text { Total Dose } \\
\text { (person- } \\
\text { rem/yr) } \\
\end{array}$ & $\begin{array}{l}\text { Dose/Person } \\
\text { (rem/yr) }\end{array}$ \\
\hline \multirow[t]{2}{*}{$\begin{array}{l}\text { Technicians } \\
\text { Crane operators } \\
\text { Riggers } \\
\text { Miliwrights } \\
\text { Supervisors - receiving/shipping } \\
\text { Supervisors - transfer/discharge } \\
\text { Crew chief - storage area } \\
\text { Inspectors - starage area }\end{array}$} & $\begin{array}{c}79 \\
11 \\
26 \\
14(+8)^{(b)} \\
8 \\
5 \\
1 \\
1\end{array}$ & $\begin{array}{c}34,300 \\
15,700 \\
22,200 \\
6,470 \\
0 \\
0 \\
624 \\
148\end{array}$ & $\begin{array}{r}131 . \\
23.9 \\
113 \\
46.3 \\
0 \\
0 \\
3.66 \\
1.21 \\
\end{array}$ & $\begin{array}{l}48.3 \\
0 \\
7.74 \\
8.27 \\
7.50 \\
4.69 \\
0.08 \\
0.14\end{array}$ & $\begin{array}{l}2.47 \\
0.34 \\
0.81 \\
0.44 \\
0.25 \\
0.16 \\
0.03 \\
0.03\end{array}$ & $\begin{array}{r}182 \\
24.2 \\
121 \\
55.0 \\
7.75 \\
4.84 \\
3.77 \\
1.38 \\
\end{array}$ & $\begin{array}{l}2.30 \\
2.20 \\
4.66 \\
2.50 \\
0.97 \\
0.97 \\
3.77 \\
1.38\end{array}$ \\
\hline & & 79,400 & 319. & & & 408. & \\
\hline
\end{tabular}

(a) Worker-hr estimate for speciftc tasks exceeds $5 \mathrm{hr} /$ person/day.

(b) The 8 millwrights rotating in from the site services bullding are considered in the calculation of average dose/person. 
TABLE 13. Transfer of Waste Canisters from Process Cells into Transfer Shields and Emplacement in the Drywell Storage Area (Preliminary Estimates)

\begin{tabular}{|c|c|c|c|c|c|c|}
\hline Personnel & $\begin{array}{l}\text { Number of } \\
\text { Personnel } \\
\text { Required/ } \\
\text { Task } \\
\end{array}$ & $\begin{array}{l}\text { T1me }(m+n / \\
\text { canister) }\end{array}$ & $\begin{array}{l}\text { Canis- } \\
\text { ters/ } \\
\text { year }\end{array}$ & $\begin{array}{l}\text { Worker- } \\
\text { hr/year }\end{array}$ & $\begin{array}{l}\text { Dose Rate } \\
\text { (mrem/hr) }\end{array}$ & $\begin{array}{c}\text { Dose } \\
\text { (person- } \\
\text { rem/yr) }\end{array}$ \\
\hline $\begin{array}{l}\text { Transport oper-1 } \\
\text { Technican }\end{array}$ & $\begin{array}{l}1 \\
1\end{array}$ & $\begin{array}{l}5 \\
5\end{array}$ & $\begin{array}{l}3,928 \\
3,928\end{array}$ & $\begin{array}{l}327 \\
327\end{array}$ & $\begin{array}{l}0.75 \\
0.75\end{array}$ & $\begin{array}{l}0.2 \\
0.2\end{array}$ \\
\hline $\begin{array}{l}\text { Transport oper-1 } \\
\text { Technictan }\end{array}$ & $\begin{array}{l}1 \\
2\end{array}$ & $\begin{array}{l}10 \\
15\end{array}$ & $\begin{array}{l}3,928 \\
3,928\end{array}$ & $\begin{array}{r}655 \\
1,960\end{array}$ & $\begin{array}{l}0.75 \\
0.75\end{array}$ & $\begin{array}{l}0.491 \\
1.47\end{array}$ \\
\hline
\end{tabular}

Position transfer shield under exit port, engage contamination barrier close shadow shield and Techrician

Loadout fuel - remote

Disengage contamination barrier, move transfer shleld into corridor prepare for storage

Technictan

ransport oper-1

Technician

Technician

Crew chief

Transport oper-1

Technician

Crew chief

Transport oper-1

Techniclan

Crew chlef

Place storage canister in drywell

Transport oper-1

Technician

Crew chief

Transport oper-1

Technictan

Crew chief

Transport oper-1

Transport oper-2
3,928

3,928

3,928

655

655
655

0.75

2.50

10.00

0.491

1.64

6.55

$928 \quad 655$

327

0.10

0.10

0.065

3,928

1,310

2.50

3.27

$3,928 \quad 2,620$

1,310

0.10

0.10

0.262

0.131

3,928

3,928

655

1,310

2.50

8.00

2.50

1.64

10.5

1.64

3,928

3,928

655
1,310

1,310

4.00

4.00

2.62

5.24

2.62

3,928

3,928

655
1,310

1.00

1.00
1.00

0.655

1.31

0.655

0.131

3,928

1,310

0.10

0.10

0.033

(yr)

\section{6}

491


Table 13 (Contd)

\begin{tabular}{|c|c|c|c|c|c|c|c|}
\hline Task & Personnel & $\begin{array}{l}\text { Number of } \\
\text { Personne } 1 \\
\text { Required/ } \\
\text { Task } \\
\end{array}$ & $\begin{array}{l}\text { Time (nin) } \\
\text { canister) } \\
\end{array}$ & $\begin{array}{l}\text { Canis- } \\
\text { ters/ } \\
\text { year } \\
\end{array}$ & $\begin{array}{l}\text { Worker } \\
\text { hr/year }\end{array}$ & $\begin{array}{l}\text { Dose Rate } \\
\text { (mirem/hr) }\end{array}$ & $\begin{array}{c}\text { Dose } \\
\text { (person- } \\
\text { rem/yr) }\end{array}$ \\
\hline Place drywell cover & $\begin{array}{l}\text { Iransport oper-2 } \\
\text { Technician } \\
\text { Crew chief }\end{array}$ & $\begin{array}{l}1 \\
2 \\
1\end{array}$ & $\begin{array}{l}10 \\
10 \\
10\end{array}$ & $\begin{array}{l}3,928 \\
3,928 \\
3,928\end{array}$ & $\begin{array}{r}655 \\
1,310 \\
655\end{array}$ & $\begin{array}{l}0.10 \\
5.00 \\
0.10\end{array}$ & $\begin{array}{l}0.065 \\
6.55 \\
0.065\end{array}$ \\
\hline Return cover-crane transport & Transport oper-2 & 1 & 5 & 3,928 & 327 & 0.10 & 0.033 \\
\hline Set up welder & $\begin{array}{l}\text { Technician } \\
\text { Crew chief }\end{array}$ & $\begin{array}{l}2 \\
1\end{array}$ & $\begin{array}{l}10 \\
10\end{array}$ & $\begin{array}{l}3,928 \\
3,928\end{array}$ & $\begin{array}{r}1,310 \\
655\end{array}$ & $\begin{array}{l}5.00 \\
0.10\end{array}$ & $\begin{array}{l}6.55 \\
0.065\end{array}$ \\
\hline $\begin{array}{l}\text { Perform remote welding of } \\
\text { cover on drywell }\end{array}$ & $\begin{array}{l}\text { Technictan } \\
\text { Crew chief }\end{array}$ & $\begin{array}{l}2 \\
1\end{array}$ & $\begin{array}{l}60 \\
60\end{array}$ & $\begin{array}{l}3,928 \\
3,928\end{array}$ & $\begin{array}{l}7,860 \\
3,930\end{array}$ & $\begin{array}{l}0.10 \\
0.10\end{array}$ & $\begin{array}{l}0.786 \\
0.393\end{array}$ \\
\hline Remove welder & $\begin{array}{l}\text { Technician } \\
\text { Crew chief }\end{array}$ & $\begin{array}{l}2 \\
1\end{array}$ & $\begin{array}{l}5 \\
5\end{array}$ & $\begin{array}{l}3,928 \\
3,928\end{array}$ & $\begin{array}{l}655 \\
327\end{array}$ & $\begin{array}{l}5.00 \\
0.10\end{array}$ & $\begin{array}{l}3.27 \\
0.033\end{array}$ \\
\hline Inspect weld & $\begin{array}{l}\text { Technician } \\
\text { Technician } \\
\text { Crew chief }\end{array}$ & $\begin{array}{l}2 \\
2 \\
1\end{array}$ & $\begin{array}{l}10 \\
30 \\
40\end{array}$ & $\begin{array}{l}3,928 \\
3,928 \\
3,928\end{array}$ & $\begin{array}{l}1,310 \\
3,930 \\
2,620\end{array}$ & $\begin{array}{l}5.00 \\
0.10 \\
0.10\end{array}$ & $\begin{array}{l}6.55 \\
0.393 \\
0.262\end{array}$ \\
\hline Clean weld & $\begin{array}{l}\text { Technictan } \\
\text { Crew chlef }\end{array}$ & $\begin{array}{l}2 \\
1\end{array}$ & $\begin{array}{l}15 \\
15\end{array}$ & $\begin{array}{l}3,928 \\
3,928\end{array}$ & $\begin{array}{r}1,960 \\
982\end{array}$ & $\begin{array}{l}5.00 \\
0.10\end{array}$ & $\begin{array}{l}9.82 \\
0.098\end{array}$ \\
\hline Hook up instrumentation & $\begin{array}{l}\text { Technician } \\
\text { Crew chief }\end{array}$ & 2 & $\begin{array}{l}15 \\
15\end{array}$ & $\begin{array}{l}3,928 \\
3,928\end{array}$ & $\begin{array}{r}1,960 \\
982\end{array}$ & $\begin{array}{l}5.00 \\
0.10\end{array}$ & $\begin{array}{l}9.82 \\
0.098\end{array}$ \\
\hline \multirow[t]{2}{*}{ Drive out of storage area } & $\begin{array}{l}\text { Technician } \\
\text { Crew chief }\end{array}$ & $\begin{array}{l}2 \\
1\end{array}$ & $\begin{array}{l}5 \\
5\end{array}$ & $\begin{array}{l}3,928 \\
3,928\end{array}$ & $\begin{array}{r}655 \\
327 \\
\end{array}$ & $\begin{array}{l}0.10 \\
0.10\end{array}$ & $\begin{array}{l}0.065 \\
\underline{0.033} \\
\end{array}$ \\
\hline & & & & & 53,400 & & 86.9 \\
\hline
\end{tabular}


TABLE 14. Surveillance and Inspection of Drywells (Preliminary Estimates)

\begin{tabular}{|c|c|c|c|c|c|c|c|c|}
\hline & Task & \multirow[t]{2}{*}{ Personnel } & \multirow[t]{2}{*}{$\begin{array}{l}\text { Number of } \\
\text { Personnel } \\
\text { Required/ } \\
\text { Task } \\
\end{array}$} & \multirow[t]{2}{*}{$\begin{array}{c}\text { Time } \\
\text { (min/ } \\
\text { drywel1) }\end{array}$} & \multirow[t]{2}{*}{$\begin{array}{l}\text { Drywells/ } \\
\text { year }\end{array}$} & \multirow[t]{2}{*}{$\begin{array}{l}\text { Morker- } \\
\text { hr/year }\end{array}$} & \multirow[t]{2}{*}{$\begin{array}{l}\text { Dose Rate } \\
\text { (mrem/hr) }\end{array}$} & \multirow[t]{2}{*}{$\begin{array}{l}\text { Oose } \\
\text { (person- } \\
\text { rem/yr } \\
\end{array}$} \\
\hline & Monitoring & & & & & & & \\
\hline \multirow[t]{4}{*}{$\unlhd$} & In transit between drywells & $\begin{array}{l}\text { Technician } \\
\text { Crew Chlef }\end{array}$ & $\begin{array}{l}2 \\
1\end{array}$ & $\begin{array}{l}0.5 \\
0.5\end{array}$ & $\begin{array}{l}16,328 \\
16,328\end{array}$ & $\begin{array}{l}272 \\
136\end{array}$ & $\begin{array}{l}0.1 \\
0.1\end{array}$ & $\begin{array}{l}0.027 \\
0.014\end{array}$ \\
\hline & \multicolumn{8}{|l|}{ Accountability } \\
\hline & Inspect & Inspector & 1 & $\begin{array}{l}2 \\
0.5\end{array}$ & $\begin{array}{l}16,328 \\
16,328\end{array}$ & $\begin{array}{l}544 \\
136\end{array}$ & $\begin{array}{l}2.0 \\
0.1\end{array}$ & $\begin{array}{l}1.09 \\
0.014\end{array}$ \\
\hline & Record & Technician & 1 & 2.5 & 16.328 & 680 & 0.1 & $\underline{0.068}$ \\
\hline
\end{tabular}


TABLE 15. Retrieval of Waste Canisters from Drywel1 Storage Area and Transfer into Process Cells (Preliminary Estimates)

\begin{tabular}{|c|c|c|c|c|c|c|}
\hline Personnel & $\begin{array}{c}\text { Number of } \\
\text { Persorinel } \\
\text { Required/ } \\
\text { Iask } \\
\end{array}$ & $\begin{array}{r}\text { Time (min) } \\
\text { canister) }\end{array}$ & $\begin{array}{l}\text { Canis- } \\
\text { ters/ } \\
\text { year } \\
\end{array}$ & $\begin{array}{l}\text { Worker- } \\
\text { hr/year }\end{array}$ & $\begin{array}{l}\text { Dose Rate } \\
\text { (mrem/hr) } \\
\end{array}$ & $\begin{array}{c}\text { Dose } \\
\text { (person- } \\
\text { rem/yr) }\end{array}$ \\
\hline Technician & 2 & $\cdot 10$ & 3,928 & 1,310 & 0.75 & 0.982 \\
\hline $\begin{array}{l}\text { Technician } \\
\text { Crew chief }\end{array}$ & $\begin{array}{l}2 \\
1\end{array}$ & $\begin{array}{l}5 \\
5\end{array}$ & $\begin{array}{l}3,928 \\
3,928\end{array}$ & $\begin{array}{l}655 \\
327\end{array}$ & $\begin{array}{l}0.10 \\
0.10\end{array}$ & $\begin{array}{l}0.065 \\
0.033\end{array}$ \\
\hline $\begin{array}{l}\text { Technictian } \\
\text { Crew chief }\end{array}$ & $\begin{array}{l}2 \\
1\end{array}$ & $\begin{array}{l}5 \\
5\end{array}$ & $\begin{array}{l}3,928 \\
3,928\end{array}$ & $\begin{array}{l}655 \\
327\end{array}$ & $\begin{array}{l}5.00 \\
0.10\end{array}$ & $\begin{array}{l}3.27 \\
0.033\end{array}$ \\
\hline $\begin{array}{l}\text { Technician } \\
\text { Crew chlef }\end{array}$ & $\begin{array}{l}2 \\
1\end{array}$ & $\begin{array}{l}15 \\
15\end{array}$ & $\begin{array}{l}3,928 \\
3,928\end{array}$ & $\begin{array}{r}1,960 \\
982\end{array}$ & $\begin{array}{l}5.00 \\
0.10\end{array}$ & $\begin{array}{l}9.82 \\
0.098\end{array}$ \\
\hline $\begin{array}{l}\text { Technician } \\
\text { Crew chief }\end{array}$ & $\begin{array}{l}2 \\
1\end{array}$ & $\begin{array}{l}65 \\
65\end{array}$ & $\begin{array}{l}3,928 \\
3,928\end{array}$ & $\begin{array}{l}8,510 \\
4,260\end{array}$ & $\begin{array}{l}0.10 \\
0.10\end{array}$ & $\begin{array}{l}0.851 \\
0.426\end{array}$ \\
\hline $\begin{array}{l}\text { Technictan } \\
\text { Crew chief }\end{array}$ & $\begin{array}{l}2 \\
1\end{array}$ & $\begin{array}{l}10 \\
10\end{array}$ & $\begin{array}{l}3,928 \\
3,928\end{array}$ & $\begin{array}{r}1,310 \\
655\end{array}$ & $\begin{array}{l}5.00 \\
0.10\end{array}$ & $\begin{array}{l}6.55 \\
0.065\end{array}$ \\
\hline Transport oper-2 & 1 & 5 & 3,928 & 327 & 0.10 & 0.033 \\
\hline $\begin{array}{l}\text { Transport oper-2 } \\
\text { Technician } \\
\text { Crew chief }\end{array}$ & $\begin{array}{l}1 \\
2 \\
1\end{array}$ & $\begin{array}{l}10 \\
10 \\
10\end{array}$ & $\begin{array}{l}3,928 \\
3,928 \\
3,928\end{array}$ & $\begin{array}{r}655 \\
1,310 \\
655\end{array}$ & $\begin{array}{l}0.10 \\
5.00 \\
0.10\end{array}$ & $\begin{array}{l}0.065 \\
6.55 \\
0.065\end{array}$ \\
\hline Transport oper-2 & 1 & 5 & 3,928 & 327 & 0.10 & 0.033 \\
\hline Transport oper-1 & 1 & 20 & 3,928 & 1,310 & 0.10 & 0.131 \\
\hline $\begin{array}{l}\text { Transport oper-1 } \\
\text { Technictan } \\
\text { Crew chief }\end{array}$ & $\begin{array}{l}1 \\
2 \\
1\end{array}$ & $\begin{array}{l}10 \\
10 \\
10\end{array}$ & $\begin{array}{l}3,928 \\
3,928 \\
3,928\end{array}$ & $\begin{array}{r}655 \\
1,310 \\
655\end{array}$ & $\begin{array}{l}0.10 \\
0.10 \\
0.10\end{array}$ & $\begin{array}{l}0.065 \\
0.131 \\
0.065\end{array}$ \\
\hline $\begin{array}{l}\text { Transport oper-1 } \\
\text { Technician } \\
\text { Crew chief }\end{array}$ & $\begin{array}{l}1 \\
2 \\
1\end{array}$ & $\begin{array}{l}10 \\
10 \\
10\end{array}$ & $\begin{array}{l}3,928 \\
3,928 \\
3,928\end{array}$ & $\begin{array}{r}655 \\
1,310 \\
655\end{array}$ & $\begin{array}{l}1.00 \\
1.00 \\
1.00\end{array}$ & $\begin{array}{l}0.065 \\
0.131 \\
0.065\end{array}$ \\
\hline $\begin{array}{l}\text { Iransport oper-1 } \\
\text { Technician } \\
\text { Crew chief }\end{array}$ & $\begin{array}{l}1 \\
2 \\
1\end{array}$ & $\begin{array}{l}10 \\
10 \\
10\end{array}$ & $\begin{array}{l}3,928 \\
3,928 \\
3,928\end{array}$ & $\begin{array}{r}655 \\
1,310 \\
655\end{array}$ & $\begin{array}{l}4.00 \\
4.00 \\
4.00\end{array}$ & $\begin{array}{l}2.62 \\
5.24 \\
2.62\end{array}$ \\
\hline
\end{tabular}


Table 15 (Contd)

\begin{tabular}{|c|c|c|c|c|c|c|c|}
\hline Task & Personnel & $\begin{array}{l}\text { Number of } \\
\text { Personnel } \\
\text { Required/ } \\
\text { Task } \\
\end{array}$ & $\begin{array}{r}\text { Time (min/ } \\
\text { canister) } \\
\end{array}$ & $\begin{array}{l}\text { Canis- } \\
\text { ters/ } \\
\text { year } \\
\end{array}$ & $\begin{array}{l}\text { Worker- } \\
\text { hr/year }\end{array}$ & $\begin{array}{l}\text { Dose Rate } \\
\text { (mrem/hr) } \\
\end{array}$ & $\begin{array}{l}\text { Dose } \\
\text { (person- } \\
\text { rem/yr) }\end{array}$ \\
\hline Decon drywell if necessary (2\%) & Technician & 2 & 80 & 79 & 211 & 1,00 & 0.211 \\
\hline $\begin{array}{l}\text { Drive transporter and pickup out } \\
\text { of yard }\end{array}$ & $\begin{array}{l}\text { Transport oper-1 } \\
\text { Technician } \\
\text { Crew chief }\end{array}$ & $\begin{array}{l}1 \\
2 \\
1\end{array}$ & $\begin{array}{r}20 \\
5 \\
5\end{array}$ & $\begin{array}{l}3,928 \\
3,928 \\
3,928\end{array}$ & $\begin{array}{r}1,310 \\
655 \\
327\end{array}$ & $\begin{array}{l}2.50 \\
0.10 \\
0.10\end{array}$ & $\begin{array}{l}3.27 \\
0.065 \\
0.033\end{array}$ \\
\hline $\begin{array}{l}\text { Position transfer shield under } \\
\text { exit port, engage contamination } \\
\text { barrter, close shadow shield and } \\
\text { door }\end{array}$ & $\begin{array}{l}\text { Transport oper-1 } \\
\text { Technician }\end{array}$ & $\begin{array}{l}1 \\
2\end{array}$ & $\begin{array}{l}10 \\
15\end{array}$ & $\begin{array}{l}3,928 \\
3,928\end{array}$ & $\begin{array}{r}655 \\
1,960\end{array}$ & $\begin{array}{r}2.50 \\
10.00\end{array}$ & $\begin{array}{l}1.64 \\
19.6\end{array}$ \\
\hline \multicolumn{8}{|l|}{ Unload fuel - remote } \\
\hline \multirow[t]{2}{*}{$\begin{array}{l}\text { Oisengage contanination barrier, } \\
\text { move transporter into corridor }\end{array}$} & $\begin{array}{l}\text { Transport oper-1 } \\
\text { Technician }\end{array}$ & $\begin{array}{l}1 \\
2\end{array}$ & $\begin{array}{l}10 \\
10\end{array}$ & $\begin{array}{l}3,928 \\
3,928\end{array}$ & $\begin{array}{r}655 \\
1,310 \\
\end{array}$ & 0.75 & $\begin{array}{l}0.491 \\
0.982 \\
\end{array}$ \\
\hline & & & & & 40,500 & & 65.4 \\
\hline
\end{tabular}


TABLE 16. Summary of Task Dose from Spent-Fuel Receipt, Storage and Shipment Operations - Alternate Storage Concept (Preliminary Estimates)

\begin{tabular}{|c|c|c|}
\hline Perso & $\begin{array}{c}\text { Task Hours } \\
\text { (worker-hr/yr) }\end{array}$ & $\begin{array}{c}\text { Task Dose } \\
\text { (person-rem/yr) } \\
\end{array}$ \\
\hline \multicolumn{3}{|c|}{ Receipt, Inspection, Unloading } \\
\hline \multirow[t]{2}{*}{$\begin{array}{l}\text { Technicians } \\
\text { Crane operators } \\
\text { Riggers } \\
\text { Miliwrights }\end{array}$} & $\begin{array}{r}10,816 \\
5,411 \\
9,214 \\
3,608 \\
\end{array}$ & $\begin{array}{r}56.5 \\
8.5 \\
57.2 \\
25.8 \\
\end{array}$ \\
\hline & 29,049 & 148.0 \\
\hline \multicolumn{3}{|c|}{ Iransfer to Transfer Shield } \\
\hline \multirow[t]{2}{*}{$\begin{array}{l}\text { Technicians } \\
\text { Crane operators }\end{array}$} & $\begin{array}{l}3,601 \\
1,637 \\
\end{array}$ & $\begin{array}{l}8.8 \\
2.4 \\
\end{array}$ \\
\hline & 5,238 & 11.2 \\
\hline \multicolumn{3}{|c|}{ Emplacement in Drywe 11 Storage Area } \\
\hline \multirow[t]{2}{*}{$\begin{array}{l}\text { Technicians } \\
\text { Crane operators } \\
\text { Crew chief }\end{array}$} & $\begin{array}{r}28,150 \\
5,892 \\
14,075 \\
\end{array}$ & $\begin{array}{r}61.1 \\
8.4 \\
6.1 \\
\end{array}$ \\
\hline & 48,117 & 75.6 \\
\hline \multicolumn{3}{|c|}{ Surveillance in Drywell Storage Area } \\
\hline \multirow[t]{2}{*}{$\begin{array}{l}\text { Technicians } \\
\text { Inspector } \\
\text { Crew chief }\end{array}$} & $\begin{array}{r}2,495 \\
686 \\
686 \\
\end{array}$ & $\begin{array}{l}3.5 \\
1.1 \\
0.1 \\
\end{array}$ \\
\hline & 3,867 & 4.7 \\
\hline \multicolumn{3}{|c|}{ Retriteval from Drywell Storage Area } \\
\hline \multirow[t]{2}{*}{$\begin{array}{l}\text { Technicians } \\
\text { Crane operators } \\
\text { Crew chief }\end{array}$} & $\begin{array}{r}20,506 \\
5,891 \\
9,493 \\
\end{array}$ & $\begin{array}{r}35.0 \\
6.7 \\
4.1 \\
\end{array}$ \\
\hline & 35,890 & 45.8 \\
\hline \multicolumn{3}{|c|}{ Transfer to Process Cell } \\
\hline \multirow[t]{2}{*}{$\begin{array}{l}\text { Technicians } \\
\text { Crane operators }\end{array}$} & $\begin{array}{l}3,273 \\
1,310 \\
\end{array}$ & $\begin{array}{r}20.6 \\
2.3 \\
\end{array}$ \\
\hline & 4,583 & 22.9 \\
\hline \multicolumn{3}{|c|}{ Shipment to Repository } \\
\hline \multirow[t]{3}{*}{$\begin{array}{l}\text { Technicians } \\
\text { Crane operators } \\
\text { Riggers } \\
\text { Miliwrights }\end{array}$} & $\begin{array}{r}16,444 \\
8,024 \\
12,970 \\
2,858 \\
\end{array}$ & $\begin{array}{r}55.0 \\
9.9 \\
55.5 \\
20.5 \\
\end{array}$ \\
\hline & 40,296 & 140.9 \\
\hline & 167,040 & 449.1 \\
\hline
\end{tabular}


TABLE 17. Annual Dose to the Receiving and Storage Crew Alternate Storage Concept (Prel iminary Estimate)

\begin{tabular}{|c|c|c|}
\hline $\begin{array}{l}\text { Number of } \\
\text { Personne } 1\end{array}$ & $\begin{array}{c}\text { Task } \\
\text { (worker-hr) }\end{array}$ & $\begin{array}{l}\text { Task Dose } \\
\text { (person- } \\
\text { rem/yr) }\end{array}$ \\
\hline \multirow[t]{2}{*}{$\begin{array}{c}85 \\
17 \\
26 \\
14(+8)(b) \\
8 \\
5 \\
4 \\
4\end{array}$} & $\begin{array}{c}85,300 \\
28,200 \\
22,200 \\
6,470 \\
0 \\
0 \\
24,300 \\
686\end{array}$ & $\begin{array}{r}241 \\
38.3 \\
113 \\
46.3 \\
0 \\
0 \\
10.3 \\
1.11\end{array}$ \\
\hline & 167,000 & 450. \\
\hline
\end{tabular}

$\begin{array}{cc}\text { Zone } & \text { Non-Zone } \\ \text { Background } & \text { Background } \\ \text { Dose (person- } & \text { Dose (perso }\end{array}$

Total Dose

Personnel

$\mathrm{rem} / \mathrm{yr}$.

rem/yr

Technicians
Crane operators
Riggers
Mtiliwrights
Supervisors - receiving/shipping
Supervisors - transfer/discharge
Crew chiefs - storage area
Inspectors - storage area

16.36

2.65

ren $/ \mathrm{yr}$ )

Dose/Person

450.

$\begin{array}{ll}0 & 0.53 \\ 7.74 & 0.81 \\ 8.27 & 0.44 \\ 7.5 & 0.25 \\ 4.69 & 0.16 \\ 0 & 0.125 \\ 0.54 & 0.125\end{array}$

259

38.8

(rem/yr)

d) Worker-hr estimate for specific tasks exceeds $5 \mathrm{hr} /$ person/day.

(b) The 8 millwrights rotating in from the site services building are considered in the calculation of average dose/person. 
TABLE 18. Dose Estimates for the 0ther Radiation Worker Crew

\begin{tabular}{|c|c|c|c|c|c|c|c|}
\hline & & $\begin{array}{l}\text { Total Ho } \\
\text { in Area }\end{array}$ & $\begin{array}{l}5 \text { Each D } \\
\text { th Dose }\end{array}$ & $\begin{array}{l}\text { Spent } \\
\text { te of }\end{array}$ & & Total Dose & \\
\hline $\begin{array}{l}\text { Number of } \\
\text { Personnel }\end{array}$ & $\begin{array}{c}\overline{0} . \overline{0} \\
\mathrm{mrem} / \mathrm{hr}\end{array}$ & $\begin{array}{l}0.125 \\
m r e m / h r\end{array}$ & $\begin{array}{c}0.25 \\
\mathrm{mrem} / \mathrm{hr}\end{array}$ & $\begin{array}{c}0.75 \\
\mathrm{mrem} / \mathrm{hr}\end{array}$ & $\begin{array}{c}2.5 \\
\mathrm{mrem} / \mathrm{hr}\end{array}$ & $\begin{array}{l}\text { (person- } \\
\text { reni/yr) }\end{array}$ & $\begin{array}{c}\text { Average Dose } \\
\text { (rem/yr) }\end{array}$ \\
\hline
\end{tabular}

Maintenance and Services

\title{
Supervisor
}

Crew Supervisors

Process Cell and Radwaste Tech

Crane Maintenance Technician

Cold and Remote Maint. Tech.

Control Room

Control Roo

Matls, Receiving and Storage

Personnel

mrem/hr

$\mathrm{mrem} / \mathrm{hr}$

$\mathrm{em} / \mathrm{hr} \quad \mathrm{mrem} / \mathrm{hr}$

$(r e m / y r)$

Shielded Process Cell Operators

Crew Supervisors

Unloading Technician

Consolidation Technician

Welding, Loadout and Decon. Tech.

1
5
15
3
2
20
2
2

2
2
2
2
2
2
2
8

$\begin{array}{ll}5 & 1 \\ 4 & 1 \\ 3 & 3 \\ 4 & \\ 4 & \\ 6 & \\ 2 & 4\end{array}$

0.22
4.06
4.22
4.12
2.75
3.75
0.62
0.00

0.22

0.81

0.28

1. 38

1. 38

0.31

$\begin{array}{ll}0.62 & 0.31 \\ 0.00 & 0.00\end{array}$

\section{Analytical Laboratory}

\begin{abstract}
Supervisor
Data Management

Lab Specialist

Lab Tech.
\end{abstract}

17

16

ealth Physics

Superytson

Lead Technician

HP Tech - Access Control

Rout ine Program Sup.

Maint/Oper Support

TOTAL HP Techs

$\begin{array}{ll}2 & 6 \\ 2 & 6 \\ 2 & 6 \\ 2 & 6\end{array}$

3.19

3.00

6.00
4.50

0.19

0.19

$\begin{array}{ll}1 & 2 \\ 1 & 2 \\ 4 & 2 \\ 8 & 2\end{array}$

0.34

0.34

1.38
2.75

0.34

0.34

0.34
0.34

Manipulator/Crane Storage and Mintenance Room

Jechnicians

HVAC Ma intenance

Operation and Maintenance Jech 
TABLE 19. Results of Variation of Design Basis Assumptions - Primary Storage Concept

\begin{tabular}{|c|c|c|c|c|c|}
\hline \multirow[b]{2}{*}{ Personnel } & \multirow[b]{2}{*}{$\begin{array}{l}\text { Number of } \\
\text { Personne1 }\end{array}$} & \multicolumn{4}{|c|}{ Average Dose/person (rem/yr) ${ }^{(a)}$} \\
\hline & & Base Case & $\begin{array}{c}\text { Remote } \\
\text { Operations } \\
\end{array}$ & $\begin{array}{l}\text { Background } \\
\text { Dose Rate - } \\
0.4 \mathrm{mrem} / \mathrm{hr} \\
\text { Instead of } \\
0.75 \mathrm{mrem} / \mathrm{hr} \\
\end{array}$ & $\begin{array}{l}\text { Throughput } \\
3,000 \mathrm{MTU} / \mathrm{yr} \\
\text { Instead of } \\
3,600 \mathrm{MTU} / \mathrm{yr}\end{array}$ \\
\hline $\begin{array}{l}\text { Technicians } \\
\text { Crane Operators } \\
\text { Riggers } \\
\text { Miliwrights } \\
\text { Supervisors - receiving/shipping } \\
\text { Supervisors - transfer/discharge } \\
\text { Crew Chief - storage area } \\
\text { Inspectors - storage area }\end{array}$ & $\begin{array}{r}79 \\
11 \\
26 \\
22 \\
8 \\
5 \\
1 \\
1\end{array}$ & $\begin{array}{l}2.30 \\
2.20 \\
4.66 \\
2.50 \\
0.97 \\
0.97 \\
3.77 \\
1.38\end{array}$ & $\begin{array}{l}1.82 \\
1.83 \\
1.72 \\
1.69 \\
0.97 \\
0.97 \\
3.77 \\
1.38\end{array}$ & $\begin{array}{l}1.94 \\
1.94 \\
4.34 \\
2.28 \\
0.53 \\
0.53 \\
3.77 \\
1.38\end{array}$ & $\begin{array}{l}2.09 \\
1.89 \\
4.05 \\
2.19 \\
0.97 \\
0.97 \\
3.26 \\
1.38\end{array}$ \\
\hline
\end{tabular}

(a) Each change in assumptions is distinct; doses were not estimated for varying two or three assumptions at once. 
TABLE 20. Results of Variation of Design Basis Assumptions - Alternate Storage Concept

Personne

\section{Technicians}

Crane 0perators

Riggers

\begin{tabular}{|c|c|c|c|c|}
\hline \multirow[b]{2}{*}{$\begin{array}{l}\text { Number of } \\
\text { Personnel }\end{array}$} & \multicolumn{4}{|c|}{ Average Dose/person (rem/yr) ${ }^{(a)}$} \\
\hline & Base Case & $\begin{array}{c}\text { Remote } \\
\text { Operations } \\
\end{array}$ & $\begin{array}{l}\text { Background } \\
\text { Dose Rate - } \\
0.4 \mathrm{mrem} / \mathrm{hr} \\
\text { Instead of } \\
0.75 \mathrm{mrem} / \mathrm{hr}\end{array}$ & $\begin{array}{l}\text { Throughput } \\
3,000 \mathrm{MTU} / \mathrm{yr} \\
\text { Instead of } \\
3,600 \mathrm{MTU} / \mathrm{yr}\end{array}$ \\
\hline $\begin{array}{r}85 \\
17 \\
26 \\
22 \\
8 \\
5 \\
4 \\
4\end{array}$ & $\begin{array}{l}3.05 \\
2.28 \\
4.66 \\
2.50 \\
0.97 \\
0.97 \\
2.60 \\
0.44\end{array}$ & $\begin{array}{l}2.60 \\
2.04 \\
1.72 \\
1.69 \\
0.97 \\
0.97 \\
2.60 \\
0.44\end{array}$ & $\begin{array}{l}2.87 \\
2.08 \\
4.33 \\
2.28 \\
0.53 \\
0.53 \\
2.60 \\
0.44\end{array}$ & $\begin{array}{l}2.70 \\
1.91 \\
4.05 \\
2.19 \\
0.97 \\
0.97 \\
2.17 \\
0.44\end{array}$ \\
\hline
\end{tabular}

Millwrights

Supervisors - receiving/shipping

Supervisors - transfer/discharge

Crew Chief - sturaye are

Inspectors - storage area

(a) Each change in assumptions is distinct; doses were not estimated for varying two or three assumptions at once. 


\section{APPENDIX A}

BASIS FOR DOSE ESTIMATES TO WORKERS DURING THE STORAGE, SURVEILLANCE AND RETRIEVAL OF WASTE IN SEALED STORAGE CASKS 


\section{APPENDIX A}

BASIS FOR DOSE ESTIMATES TO WORKERS DURING THE STORAGE, SURVEILLANCE AND RETRIEYAL OF WASTE IN SEALED STORAGE CASKS

The procedures and amount of time required for the emplacement, surveillance (monitoring and accountability) and retrieval of the sealed storage casks from the storage area at the monitored retrievable storage (MRS) facility are based on the information given in Design Study 2, Waste Receipt and Handling Characteristics of the MRS Facility (The Ralph M. Parsons Company 1985a, Vol. VI, Book I) and in the design description in the Conceptual Design Report (The Ralph M. Parsons Company 1985a, Vol. I, Book II). Because the procedures and time estimates in those sources are not comprehensive, various assumptions were required to estimate personnel doses. The following procedures, time estimates and dose rates were used as the basis for the calculation of personnel dose during storage area operations.

The personnel requirements for the concrete cask storage and retrieval operations are given in the Conceptual Design Report (The Ralph M. Parsons Company 1985a, Vol. I, Book II). A single crew is required for emplacement, surveitlance, and retrieval of the casks. The crew consists of a transport operator, crane operator, two technicians, an inspector and a crew chief. The entire storage area crew is not required for each operation. The emplacement and retrieval operations involve the transport operator, crane operator, technicians and the crew chief. Surveillance operations require the crew chief, inspector and two technicians.

\section{EMPLACEMENT}

During the storage operation, the transport operator drives the transporter containing a concrete cask from the receiving and handling (R\&H) building to the appropriate location in the storage yard. The maximum speed of the transporter is $3 \mathrm{mph}$, and it is expected to require 30 minutes to drive from the R\&H building to the storage yard. As the transport operator nears the location where the cask is to be stored, the remaining personnel are notified by radio and they proceed in pickups to the storage area. They reach their 
destination in approximately 2.5 minutes. Upon arrival, the crane operator climbs into the 600-ton mobile storage area crane. The crane is located in the aisle between two storage pads and is positioned at the correct location for unloading the cask.

The transporter is located approximately $40 \mathrm{ft}$ from the crane during the unloading process. This distance is based on the operating radi $i$ (the distance between the crane axis of rotation and the center of the cask) of the crane during the transfer of a storage cask. The operating radius is estimated to be between 40 and $50 \mathrm{ft}$ (The Ralph M. Parsons Company 1985a, Vol. I, Book II). The cask is unloaded from the transporter and placed onto the concrete storage pad. This process requires 2.5 minutes. The first technician and the crew chief assist in the emplacement process. The second technician waits near the transport operator until the cask has been placed on the pad (about 15 minutes after the start of the emplacement process). The second technician begins to complete the themocouple instrumentation connections while the crane operator and first technician are completing the cask emplacement and disengaging the lift fixture. The thermocouple connections require a total of 25 minutes to complete.

The transport operator leaves the storage area after the cask has been removed from the transporter (15 minutes after the start of emplacement), again requiring 30 minutes to return to the $R \& H$ building. The crane is repositioned after the cask emplacement is complete. Because the crane is positioned in the middle of the aisle, two casks can be placed (one on the concrete pad to the right of the crane and the other on the pad to the left of the crane) before the crane has to be moved. After every second cask is emplaced, the crane operator moves the crane with the assistance of the first technician and the crew chief. This requires about 15 minutes. The personnel leave the storage area, requiring 2.5 minutes to return by vehicle to the R\&H building.

The exposure rates from a typical sealed storage cask were calcuiated by taking a weighted average of the expected surface dose rate from casks designed for containing consolidated fuel, intact fuel, nonfuel-bearing components, and high-level waste (The Ralph M. Parsons Company 1985a, Vol. I, 
Book II). An expected surface dose rate of $6.8 \mathrm{mrem} / \mathrm{hr}$ was calculated along the side of a typical sealed storage cask. The estimated personnel doses are based on this dose rate.

Figure A.1 illustrates the sources of exposure to the storage area crew during emplacement of a storage cask. The sources include the cask that is being emplaced and those casks that have been previously placed in the storage yard. To keep the dose rate to the storage crew as low as reasonably achievable, it is expected that the casks will be placed consecutively along each row, starting from the farthest edge of the storage facility. A considerable amount of shielding is provided by each row of casks, so that casks located in rows $D, E$ and so on, will not contribute significantly to the storage crew's dose. The dose to each member of the storage crew is calculated by summing the dose from all sources of exposure.

During the transport of the casks into the storage area, the transport operator is located $12.5 \mathrm{ft}$ from the edge of the cask. This results in a dose of $2.0 \mathrm{mrem} / \mathrm{hr}$ assuming no additional shielding. Because the casks are all stored at the far end of the storage area, the crane operator, crew chief and two technicians receive an average dose of less than $0.1 \mathrm{mrem} / \mathrm{hr}$ during their drive to the storage location.

During emplacement of the storage cask, the transport operator remains near the transporter and is exposed to radiation from the cask to be emplaced as well as casks in rows $A, B$ and $C$. The transporter operator is exposed to $5.4 \mathrm{mrem} / \mathrm{hr}$, which includes a maximum of $2 \mathrm{mrem} / \mathrm{hr}$ from the storage cask being removed from the transporter, $2.1 \mathrm{mrem} / \mathrm{hr}$ from the casks in row $\mathrm{C}$, and $1.3 \mathrm{mrem} / \mathrm{hr}$ from rows $A$ and $B$. The crane operator, located in the 600 -ton crane, is exposed to $5.1 \mathrm{mrem} / \mathrm{hr}$, which includes $0.5 \mathrm{mrem} / \mathrm{hr}$ from the cask being emplaced (a distance of $40 \mathrm{ft}$ away), $1.4 \mathrm{mrem} / \mathrm{hr}$ from casks in row $\mathrm{C}$, and $3.2 \mathrm{mrem} / \mathrm{hr}$ from casks in rows $A$ and $B$. The crew chief and one of the technicians do not remain in a constant dose rate field while providing assistance to the crane operator during emplacement of the cask; on the average they receive an estimated $6.5 \mathrm{mrem} / \mathrm{hr}$. This estimate is based on a location $20 \mathrm{ft}$ from the cask being emplaced (1.7 mirem/ $\mathrm{hr}$ ), slightly more than $40 \mathrm{ft}$ from the nearest cask in row $\mathrm{C}(1.3 \mathrm{mrem} / \mathrm{hr})$, over $50 \mathrm{ft}$ from the 

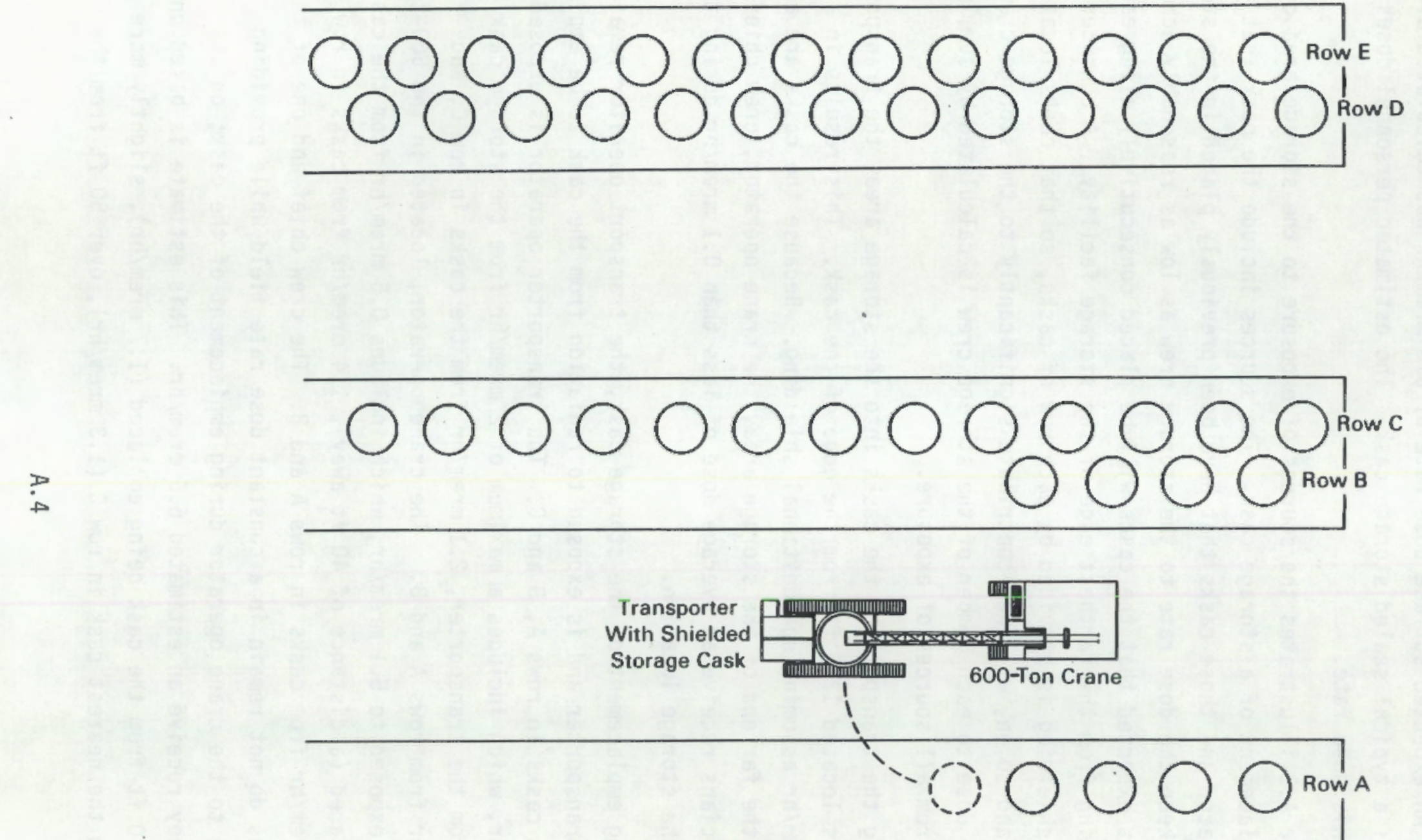
nearest cask in row $B(1.0 \mathrm{mrem} / \mathrm{hr})$, and about $25 \mathrm{ft}$ from the nearest cask in row $A(2.5 \mathrm{mrem} / \mathrm{hr})$. The second technician receives $5.4 \mathrm{mren} / \mathrm{hr}$ (the same as the transport operator) while waiting by the transporter during emplacement of the cask. After the cask has been placed on the concrete storage pad, the second technician completes the thermocouple instrumentation connections on the cask. During this period, the technician stands two feet from the cask and is exposed to a dose rate of $9.0 \mathrm{mrem} / \mathrm{hr}$, which includes $5.5 \mathrm{mrem} / \mathrm{hr}$ from the cask, $0.6 \mathrm{mrem} / \mathrm{hr}$ from the casks in row $\mathrm{C}$, and $1.0 \mathrm{mrem}$ from the casks in row $B$. The adjacent cask in row $A$ contributes $1.9 \mathrm{mrem} / \mathrm{hr}$ to the radiation field and provides shielding for the technician from the remaining casks in row $A$.

After the emplacenent process has been completed, the second technician leaves the storage area and the crane operator, crew chief and the first technician position the crane at the next storage location if required. The dose received during the movement of the crane is $5.1 \mathrm{mrem} / \mathrm{hr}$ for all three workers, who are expected to remain near the middle of the aisle. Dose rates of $0.1 \mathrm{mrem} / \mathrm{hr}$ are received by the workers as they drive out of the storage yard.

The personnel dose will be similar whether the cask is being placed in row $A$ or in row $B$. The only significant difference in dose will be to the technician who connects the thermocouples, because casks in row $B$ provide some shielding from the casks in row $C$. The higher dose received during emplacement of a cask in row $A$ was used for this analysis in order to be conservative.

\section{SURVEILLANCE}

Surveiltance of the storage area includes monitoring and accountability operations. The sealed storage casks will be monitored periodically to ensure the integrity of the cask liner and cover. Accountability operations are performed annualiy to ensure that the radioactive materials in the storage area are present (The Ralph M. Parsons Company 1985a, Vol. I, Book II).

During monitoring operations, a gas sample is obtained and analyzed to determine whether the canisters have lost their integrity. Cask liner/cover integrity is also tested by performing a pressure decay test similar to the 
one performed immediately after welding the cask cover on the cask in the transfer/discharge area of the R\&H building. The assumption was made that the pressure decay test would only be used if the gas sample indicated that the canisters had lost their integrity. Two percent of the storage casks were assumed to require periodic pressure decay tests tased on the assumption that $2 \%$ of the sealed storage cask contents would have to be decontaminated before shipment to the repository (The Ralph M. Parsons Company 1985a, Vol. VI, Book I).

The monitoring operations are performed by the storage area crew chief and two technicians. The crew chief and the first technician travel in a pickup truck along the middle of the aisle between two storage pads of concrete casks. The first technician drives the pickup truck while the crew chief keeps the records. The second technician obtains a gas sample and the temperature readings (if necessary). A period of two minutes is allotted per cask for this operation. This includes 1.5 minutes to obtain the gas sample and 0.5 minutes to return the sample to the truck, retrieve an empty sample bottle, and return to the next cask. The crew chief and the technician in the truck are exposed to a radiation field of $8.5 \mathrm{mrem} / \mathrm{hr}$. The second technician is in a field of $11.5 \mathrm{mrem} / \mathrm{hr}$ (2 feet from the cask) during the sampling process and in a varying fjeld during transit between the truck and the casks. A dose rate of $10.2 \mathrm{mrem} / \mathrm{hr}$ was assigned during this time.

The pressure decay test requires two technicians working 40 minutes each per cask. At least 10 minutes of this time is hands-on work, $2 \mathrm{ft}$ from the cask in a dose field of $11.5 \mathrm{mrem} / \mathrm{hr}$. The remaining 30 minutes is spent at Teast 5 feet from the cask in a dose field of $9.6 \mathrm{mrem} / \mathrm{hr}$.

It is expected that the casks will initially be monitored more frequently than once per year. However, after several years, the frequency of monitoring will likely decrease to once a year. For this analysis, it was assumed that $8.3 \%$ of the storage casks are monitored each month so that each cask is monitored annually. The calculations are based on 1760 casks (the capacity of the storage facility) being stored in the yard during any one year. This is a conservative assumption and it will approximately compensate for the increased frequency in monitoring during the first few years of the facility operation. 
In addition, it is likely that a reduced schedule will be implemented for monitoring the sealed storage casks that do not contain spent fuel, thus further reducing the number of casks that will require monitoring. A constant 35 casks $/ y r$ ( $2 \%$ of 1,760 casks) was used as the number of casks requiring pressure decay tests each year, even though fewer than 35 casks/yr will require pressure decay tests during the first few years of operation.

The accountability operations will be performed annually (The Ralph M. Parsons Company 1985a, Vol. I, Book II). The casks will be counted and the security seals, cask liner, and cover welds will be inspected. The accountability operations are performed by the inspector and two technicians. The inspector and one of the technicians use a cherry picker to inspect the security seals, cask liner, and cover welds. The second technician drives the cherry picker between casks. Three minutes are allotted at each cask, including the transit time between casks. The inspector and the technician responsible for recording the data receive a dose of $6.0 \mathrm{mrem} / \mathrm{hr}$ while in the cherry picker. The technician driving the cherry picker is approximately 10 feet from the cask and receives $9.0 \mathrm{mrem} / \mathrm{hr}$.

The accountability operations also involve obtaining instrument readings using portable radiation detection instrumentation at specific locations around the cask. These readings will be compared to previous readings to confirm the presence of the enclosed radioactive materials. This procedure requires an inspector and a technician; both are in a radiation field of $11.5 \mathrm{mrem} / \mathrm{hr}$ during the 2 minutes that it requires to obtain dose rates near the casks.

RETRIEVAL

The procedure for the retrieval of casks from the storage yard is the opposite of the emplacement procedure. The transporter operator drives an empty transporter into the storage area. The crew chief and one of the technicians enter the storage area and inspect the cask ( $5 \mathrm{~min})$, and the technician disconnects the thermocouple instrumentation ( 5 min) before returning in the pickup to the R\&H building. The crane operator and the second technician arrive in a second pickup and load the cask onto the 
transporter with the assistance of the crew chief. This process requires a total of 25 minutes. Once the cask is placed on the transporter, the transporter operator returns to the R\&H building. The crane operator, crew chief and the second technician either return directly to the R\&H building or move the crane to the location of the next cask ta be retrieved (15 min).

The storage crew personnel are exposed to the same dose rates during retrieval of the casks as during the emplacement process. 


\section{APPENDIX B}

BASIS FOR DOSE ESTIMATES TO WORKERS DURING THE STORAGE, SURVEILLANCE AND RETRIEVAL OF WASTE IN DRYWELL STORAGE 
APPENDIX B

BASIS FOR DOSE ESTIMATES TO WORKERS DURING THE STORAGE, SURVEILLANCE AND RETRIEVAL OF WASTE IN DRYWELL STORAGE

The procedures for the emplacement, surveillance (monitoring and accountability), and retrieval of waste canisters from drywells are found in the ConCeptual Design Report (The Ral.ph M. Parsons Company 1985a, Vol. I, Book II) and in Design Study 2, Waste Receipt and Handling Characteristics of the MRS Facility (The Ralph M. Parsons Company 1985a, Vol. VI, Book I). The latter reference gives time estimates for some of the operations. Because the procedures and time estimates were not complete, assumptions were required to calculate the dose to the personnel in the drywell storage area. The following procedures, time estimates, and dose rates were used as the basis for the calculation of dose estimates during drywell storage area operations.

The personnel requirements for the drywelt storage area are given in the Conceptual Design Report (The Ralph M. Parsons Company 1985a, Vol. I, Book II). Four crews are required for emplacement, survejllance, and retrieval of canisters. These operations occur $24 \mathrm{hr} /$ day, 7 days/week. Each of the crews consists of a crew chief, an inspector, two technicians, and two transport operators. An entire crew is not required for each operation. The emplacement and retrieval operations involve the crew chief, the technicians, and the transport operators. The surveillance operations require the crew chief, inspector, and two technicians.

\section{EMPLACEMENT}

The spent fuel canister, drums of nonfuel-bearing components, or highlevel waste are loaded into a transportable transfer shield in the receiving and handling (R\&H) building. The transfer shield is then driven by a member of the transporter crew into the storage yard and to the appropriate storage location. The transfer shield transport moves at a maximum speed of $10 \mathrm{mph}$; it takes approximately 20 minutes to complete the trip. The crew chief and the two technicians drive a pickup containing the remote welding equipment into the storage area. The trip is completed in less than 5 minutes. The 
technicians are responsible for inspecting the drywell and preparing it for storage. This requires about 20 minutes and is complete about the time the transport arrives. The technicians assist in aligning the transfer shield transport over the drywell, which requires approximately 10 minutes. The storage canisters are then placed in the drywell (10 min) and the shield plug is also moved into place $(10 \mathrm{~min})$. To reduce their dose during emplacement of the canisters and the shield plug, the transport operator, the two technicians and the crew chief are located $20 \mathrm{ft}$ from the transfer shield and operate the transfer shield remotely. After the shield plug is in place, the transport operator drives the transfer shield transport out of the storage facility. The second transport operator arrives in the drywell cover crane and transport vehicle (a pickup truck with a rear-mounted jib crane). The second transport operator uses the $j i b$ crane to place the cover on the drywell with the assistance of the two technicians. This requires 10 minutes. After the drywell cover is in place, the transport operator drives back to the R\&H building. The technicians position the welding machine and welding torch head, and the welding sequence is started from the welding process controller mounted on the remaining pickup truck. It requires 10 minutes to set up the welder and 60 minutes to weld the cover on the drywell. After the welding process is complete, the technicians remove the welding equipment (5 min) and the weld is inspected by nondestructive and leak-test methods (40 min). The weld and the heat-affected zone are cleaned and varnished ( $15 \mathrm{~min}$ ) to promote corrosion resistance. The thermocouple instrumentation connections are completed by the technicians in 15 minutes, and the technicians and crew chief drive out of the storage area.

The dose rates used in this analysis were obtained from the Calculations book of the Conceptual Design Report (The Raiph M. Parsons Company 1985a, Vol. IV, Book XIII). The transport operator is exposed to a dose rate of $2.5 \mathrm{mrem} / \mathrm{hr}$ while sitting in the shielded transport. The remaining personne 1 are exposed to $0.1 \mathrm{mrem} / \mathrm{hr}$ while they travel through the storage area. The dose rate during the inspection of the drywell before the arrival of the transportable transfer shield is also $0.1 \mathrm{mrem} / \mathrm{hr}$. The dose rates near the drywell increase after the transfer shield transport arrives. During the alignment of the transfer shield, the transport operator remains in the transfer shield transport, receiving $2.5 \mathrm{mrem} / \mathrm{hr}$. It is assumed that the 
technicians assisting with the alignment of the transfer shield do not remain in a constant dose field, so on the average they receive a dose rate of $8 \mathrm{mrem} / \mathrm{hr}$. The crew chief is located near the transport operator, and therefore receives $2.5 \mathrm{mrem} / \mathrm{hr}$. Workers are located $20 \mathrm{ft}$ from the transfer shield during the remote emplacement operation and are exposed to a radiation field of $4.0 \mathrm{mrem} / \mathrm{hr}$. After the canister is emplaced and while the shield plug is being placed in the drywe 1 , the dose rate drops to an estimated I $\mathrm{mrem} / \mathrm{hr}$. The technicians are exposed to a dose rate of $5 \mathrm{mrem} / \mathrm{hr}$ during the placement of the drywell cover on the drywell and the positioning of the welding machine. The second transport operator operating the $j i b$ crane, and the crew chief are in a dose field of $0.1 \mathrm{mrem} / \mathrm{hr}$ ( $8 \mathrm{ft}$ away). After the drywell cover is placed on the drywel1, the second transport operator returns to the R\&H buitding and the two technicians and the crew chief remain in a field of $0.1 \mathrm{mrem} / \mathrm{hr}$ during the remote welding process. After the welds are completed, the technicians remove the weld equipment in a $5 \mathrm{mrem} / \mathrm{hr}$ fjeld. The technicians spend 10 minutes in a 5.0 mrem/hr field and 30 minutes in a $0.1 \mathrm{mrem} / \mathrm{hr}$ field while inspecting and leak-testing the weld. The thermocouple connections are completed in a $5 \mathrm{mrem} / \mathrm{hr}$ field. The crew chief remains in a field of $0.1 \mathrm{mrem} / \mathrm{hr}$ during these procedures.

\section{SURVEILLANCE}

The surveillance of the drywell storage area involves periodic monitoring of the drywell liner and cover integrity, and annual accountability of the drywell contents.

The monitoring operations include visually inspecting the drywell liner/ cover and collecting a gas sample to be analyzed for the presence of gaseous fission products or canister tag gas, which indicates that canisters have lost their integrity. If the integrity of the canister is lost, a pressure decay check is conducted to ensure the integrity of the drywell covers, welds, and liner flange. The assumption was made that the pressure decay check is performed only for those drywells where the gas sample analysis indicated that there had been a failure in the integrity of the canisters. Two percent of the drywells are assumed to require periodic pressure decay tests based on the $2 \%$ of the drywell contents that have to be decontaminated before shipment to 
the repository (The Ralph M. Parsons Company 1985a, Vol. VI, Book I). In addition to these inspections, the monitoring operation includes temperature surveillance for a fixed number of drywells.

The monitoring operations are performed by the storage area crew chief and two technicians. One of the technicians obtains the gas samples and visually inspects the drywell cover, welds, and flange. This technician is located near the edge of the drywell cover for approximately 2 minutes and is in a dose field of $5 \mathrm{mrem} / \mathrm{hr}$. The second technician is driving the pickup truck, which is located between drywells in a zone of $0.1 \mathrm{mrem} / \mathrm{hr}$. The crew chief is recording the data obtained from the first technician and is also in a dose field of $0.1 \mathrm{mrem} / \mathrm{hr}$ for the two minutes required per drywell. A 30-second period of time was assumed for the first technician to return to the pickup to exchange a full gas bottle for an empty gas bottle and move to the next dryweli.

The pressure decay checks are performed by two storage area technicians and require 40 minutes. The technicians are adjacent to the drywell for 10 of the 40 minutes in a dose field of $5 \mathrm{mrem} / \mathrm{hr}$. The remaining 30 minutes, the technicians retreat to a $0.1 \mathrm{mrem} / \mathrm{hr}$ dose field.

It is expected that the drywells will initially be monitored more frequently than once per year. However, after several years the frequency of monitoring will drop to once per year. For this analysis, it was assumed that 8.3\% of the drywells are monitored each month so that each drywell is monitored annually. The calculations are based on a total of 16,328 drywells containing canisters (the capacity of the storage yard). This is a conservative assumption, but it will approximately compensate for the increased frequency in monitoring during the first few years of facility operation. A constant 326 drywelis $(2 \%$ of 16,328$)$ was used as the number of drywells requiring pressure decay checks each year, even though this number will be much lower during the first few years.

In addition, it is likely that a reduced schedule will be implemented for monitoring the drywells that do not contain spent fuel, thus further reducing the number of casks that will require monitoring. 
The accountability operations consist of identifying each drywel?, inspecting the security seals and monitoring the drywells for radiation. The accountability operations are performed by the inspector and a technician. The storage area inspector is in charge of the inspection and spends 2 minutes standing near the drywell in a zone of $2.0 \mathrm{mrem} / \mathrm{hr}$. During this time, the inspector also obtains radiation measurements around the perimeter of the drywell cover to confirm the presence of the enclosed radioactive materials. The technician records the information provided by the inspector. This technician remains in a field of $0.1 \mathrm{mrem} / \mathrm{hr}$. The technician and the inspector spend 30 seconds moving from one drywell to the next, in a dose field of $0.1 \mathrm{mrem} / \mathrm{hr}$.

\section{RETRIEVAL}

The procedure for the retrieval of the canisters from the storage yard is basically the opposite of the emplacement procedure. The crew chief and the two technicians enter the storage area, a 5 minute drive. The technicians unhook the thermocouple instrumentation ( $5 \mathrm{~min}$ ) and set up the weld cutting equipment $(15 \mathrm{~min})$. The remote cutting of the weid requires 65 minutes. The weld equipment is removed by the technicians $(10 \mathrm{~min})$ at the same time that the second transport operator arrives with the drywell cover crane to remove the drywell cover $(10 \mathrm{~min})$. After the cover has been removed, the second transport operator returns to the R\&H building and the first transport operator arrives (after a 20-min drive) with the transfer shield transport vehicle. The transfer shield is aligned with the drywell (10 min), and the shield plug and then the canister are removed from the drywe1l (10 min each). The transport and the pickup are then driven out of the drywell storage facility. It is expected that $2 \%$ of the drywells will require decontamination after the storage canister has been removed. This task is performed by the technicians and takes 80 minutes. A dose rate of $1.0 \mathrm{mrem} / \mathrm{hr}$ was estimated for this procedure. The dose rates during the retrieval of the canister from the drywell storage facility are considered to be the same as those at the comparable stage in the storage process. 



\section{REFERENCES}

Enge1, R. L., J. Greenborg and M. M. Hendrickson. 1966. ISOSHLD - A Computer Code for General Purpose Isotope Shielding Analysis. BNWL-236, Pacific Northwest Laboratory, Richland, Washington.

The Ralph M. Parsons Company. 1985a. Conceptual Design Report, Vols I-VI. Report No. MRS 11, Pasedena, California.

The Ralph M. Parsons Company. 1985b. Conceptual Basis for Design. Report No. MRS 11, Pasedena, California.

Simmons, G. L., J. J. Regimbal, J. Greenborg, E. L. Kelly Jr. and H. H. VanTuyi. 1967. ISOSHLD II Code Revision to Include Calculation of Dose Rate from Shielded Bremsstrahtung Sources. BNWL-236 Supplement I, Pacific Northwest Laboratory, Richtand, Washington.

U.S. Department of Energy (DOE). 1981. "Standards and Requirements for Radiation Protection." In DOE Order 5480.1A, Chapter XI, Washington, O.C.

U.S. Nuclear Regulatory Commission (NRC). 1983. Directory of Certificates of Compliance for Radioactive Materials Packages. NUREG-0383, VoT. 2, Rev. 6 . Washington, D.C. 
DISTRIBUTION

No. of

Copies

OFFSITE

30 DOE Technical Information Center

3 J. H. Carlson

Office of Civilian Radioactive

Management

U.S. Department of Energy

$\mathrm{RW}-32$

Washington, DC 20545

3 P. Gross

U.S. Department of Energy

Oak Ridge Operations Office

Oak Ridge, TN 37830

W. D. Woods

The Ralph M. Parsons Company

100 West Wainut Street

Pasadena, CA 91124

2 A. T. Clark

U.S. Nuclear Regulatory Commission

Willste Building

7915 Eastern Avenue

Silver Springs, MD 20901

ONSITE

5 DOE Richland Operations Office
No. of

Copies

50 Pacific Northwest Laboratory

L. W. Brackenbush

J. L. Braitman

C. P. Brim

G. W. R. Endres

T. H. Essig

J. F. Fletcher

R. M. Gale (3)

D. E. Madlock

R. J. $\mathrm{Ha} 1 \mathrm{l}$

R. Harty (18)

R. E. Heineman

D. S. Jackson

W. S. Kelly

D. K. Kreid

P. N. McDuffie

J. L. McElroy

D. F. Newman

D. R. Payson

K. J. Schneider

G. H. Sewart

R. I. Smith

G. A. Stoetzel

M. B. Triplett

Health Physics Department Library

Publishing Coordination (2)

Technical Information (5)

J. J. Sutey

R. B. Goranson

R. D. Izatt (2)

M. Dayani 
